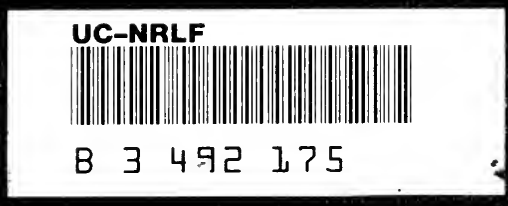

4.

6es 


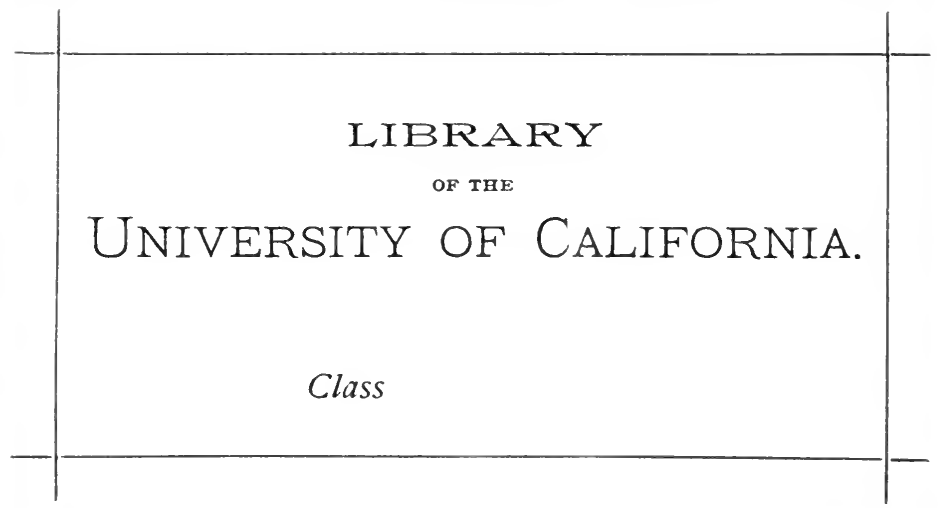




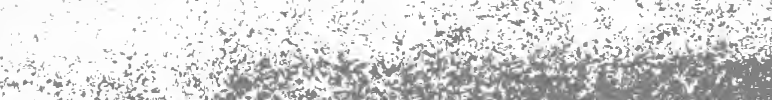

then

int

tston

intols

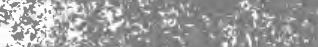

iving

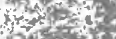

tort

rito

rest:

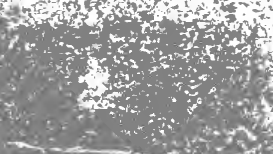

(N,

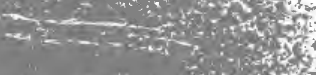

$x^{*}$

sing

50

a.

tim

into

in

I 79

$$
\text { and }
$$

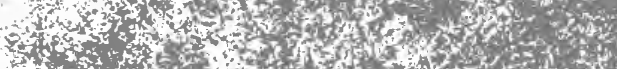

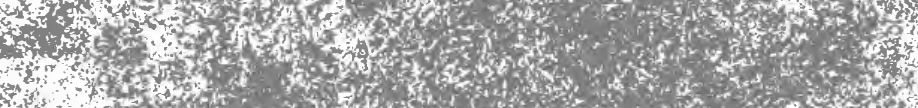
(n)

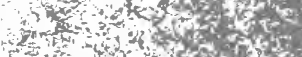

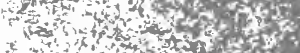

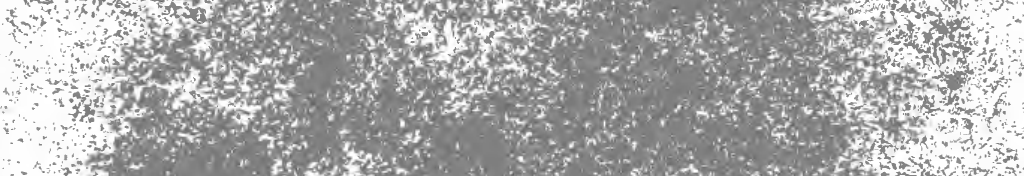

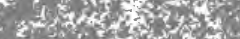
tis:

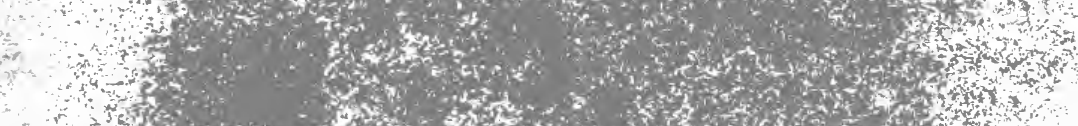
incon

2.5. in $\rightarrow$

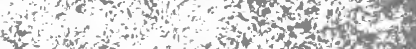

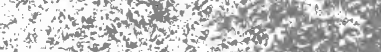

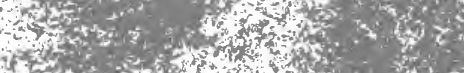

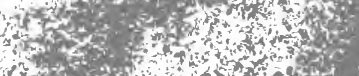

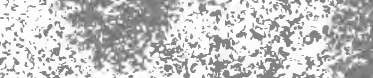

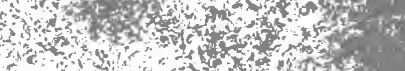

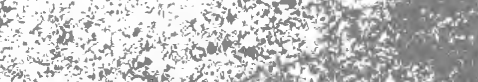

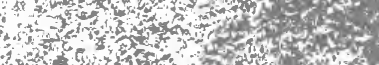
Wof

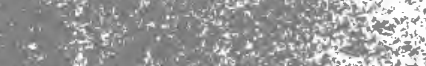
* 5040

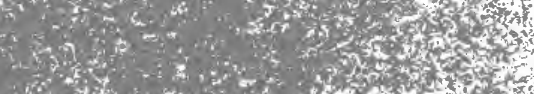

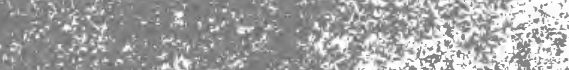

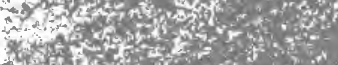

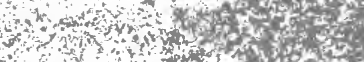

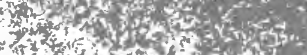





\section{CAMDEN MISCELLANY}

VOL. XII

CAMDEN THIRD SERIES

V O L. X V I I I

XIIBTE SET
OF THE
UNIVERS

UNIVERSITY

GALIFORMLA

LON DON

OFFICES OF THE SOCIETY

$6 \& 7$ SOUTH SQUARE

GRAY'S IN N

I 9 I 0 
GENERAE

peren?CALA 


\section{CONTENTS}

TWO LONDON CHRONICLES, FROM THE COLLECTIONS of John Stow. Edited by C. L. Kingsford, M.A., F.S.A., F.R.Hist.S.

LIFE OF SIR JOHN DIGBY (1605-1645). EDITED BY Georges Bernard, L.Ès-L. . . . . . 6 6

ITER BELliCOSUM: AdAM WheEler his Account of 1685. Edited by H. E. Malden, M.A., Hon. Fellow of Trinity Hall, Cambridge, V.-P. and Hon. Sec. R. Hist.S.

COMMON RIGHTS AT COTTENHAM AND STRETHAM IN CAMBRIDGESHIRE. EDITED BY W. Cunningham, D.D., F.B.A., President of the Royal Historical Society and Archdeacon of Ely . . 


\section{TWO LONDON CHRONICLES}

FROM THE COLLECTIONS OF JOH N S TOW 


\section{Digitized by the Internet Archive in 2007 with funding from Microsoft Corporation}




\section{TWO LONDON CHRONICLES}

FROM THE COLLECTIONS OF

$$
\begin{gathered}
\text { J OH N T O W } \\
\text { EDITED FOR THE }
\end{gathered}
$$

ROYAL HISTORICAL SOCIETY

B Y

CHARLES LETHBRIDGE KINGSFORD

$$
\text { M.A., F.S.A., F.R.HIST.S. }
$$

CAMDEN MISCELLANY

VOL. XII

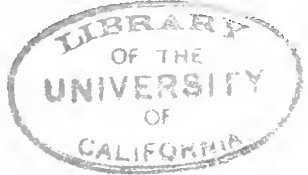

LON DON

OFFICES OF THE SOCIETY

6 \& 7 SOUTH SQUARE

GRAY'S IN N

I 9 I $O$ 


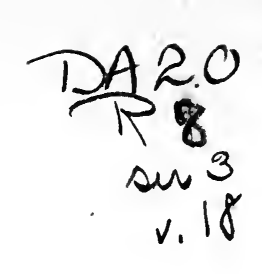




\section{IN'TRODUCTION}

The two short London Chronicles here printed are both preserved amongst the Collections of John Stow in the British Museum, and both illustrate (though in very different degrees) the manner in which he composed his History of England, beginning with his Summary of English Chronicles and ending with his better known Annales.

The first and much the more important is copied in Harley MS. 540 ff. 7-21, partly in Stow's own writing and partly by another hand. At the beginning it is stated to be 'copied out of Myster Lordynge's booke.' Who Mr Lordyng was I cannot say. But his book was probably a copy of one of the old Chronicles of London, as the four brief notes, with which the Chronicle in the Harley MS. begins, seem to indicate. It would be quite in accordance with custom for a later owner to have entered at the end of the original Chronicle from time to time a continuation of his own. This is the character of the main Chronicle here printed for the years 1523 to 1555. Really there are two separate Chronicles, entered no doubt in the original by two different owners. The first is for the years 1523 to 1540 ; the second for 1548 to 1555 . For the intervening years 1540 to 1548 the names of the mayors and sheriffs, with a single bald note under $1543-44$, had been entered, possibly by the writer of the second Chronicle. These two Chronicles of Harley MS. 540 are clearly of different authorship, having nothing in common save for certain indications that the writers of both were of anti-Protestant feelings.

The chief interest of the earlier Chronicle (1523-1540) consists in the fact that it formed the principal source for Stow's narrative in the first editions of his Summary of English Chronicles published 
in 1565 and $\mathrm{r} 566$. It is somewhat amusing to find that Stow was, for matters almost within his own memory, copying so slavishly from a written Chronicle, at the very time when he was censuring Grafton for having made an unfair use of his own printed work. ${ }^{1}$ It is true that Stow added for these years a little from Hall, but the early editions of the Summary are substantially a mere reproduction from the Chronicle here printed. In the subsequent editions of the Summary in 1570 and 1575, and still more in the final history as given in the Annales, Stow drew much more freely on other sources. A great deal of matter contained in this Chronicle was thus gradually dropped. Meantime something had been borrowed by Holinshed without any specific acknowledgement of his source. It is thus necessary to recognise that the successive editions of Stow's Summary are deserving of more attention than they have commonly received.

Though Stow for the most part followed the Chronicle very closely, his departures from his original in some places are noteworthy. The original contains certain matter, which, when Stow wrote thirty years later, it would not have been judicious to repeat. Under 1528-9 a reference to the "selling of Martin Luther's books" is omitted. " So also is that to the burning of Tyndal's books in Nov. 1530. More remarkable is the omission of the reference to Catherine of Aragon ' a blysyd lady and a good,' " and of the pathetic story of the two women, who 'fortified theyr saying still to die in the quarell for Queen Catherine's sake.' 3 On the other hand it is to be noted that the Chronicler had not recorded the proclamation of the king's supremacy in 1534 , passed over Anne Boleyn's wedding and the birth of the princess Elizabeth, and even the birth of Edward VI ; the omission to mention the suppression of the monasteries under 1537-8 may also be due to anti-Protestant sympathies, which the writer feared to express. Through Stow the Chronicle is several times quoted by Holinshed;

${ }^{1}$ Dedication of Summary Abridged for 1567 ap. Survey of London i. Ixxvii.
2 p. 3
3 p. 5
p. 7
b. 8 
as for the events of $1534-5$, for the procession on 11 Nov. 1535, the jousting at Westminster on 29 June 1536, the penance of Thomas Newman on 12 Nov. 1536, and the execution of the Vicar of Wandsworth on 8 July $1539 .^{1}$

For the most part the Chronicle consists of brief notes, probably written down immediately after the events to which they relate. Executions, penances for heresy, and incidents of civic history furnish the principal staple of the narrative. Passages of more moment, which may be mentioned, are the reference to Queen Catherine noted above, the description of the prosecution of the Maid of Kent, ${ }^{2}$ the long account of the procession on $11^{\text {th }}$ Nov. $1535,^{3}$ and the curious notice of Thomas Cromwell's alleged parentage. ${ }^{4}$

The chronology of the Chronicle calls for some explanation. The note ${ }^{5}$ that ' this boke doth accoumpte $y^{\mathrm{e}}$ yere to begyn at Novembar,' was probably inserted by Stow, who did not recognise that the years were mayoral not regnal. But the numbers of the years as given in the text have been frequently altered, the original numbers having been a year earlier ('xvj.' for 'xvij.' etc.). The explanation probably is that the original writer put down the mayor, who held office in April 1509, as the mayor for the 'first year of Henry VIII.' Thus the mayor and sheriffs for 1509-10 would have been entered as those for 2 Henry VIII ; and Thomas Baldry would have appeared under 16 Henry VIII, though he really held office $1523-24$ in the $15^{\text {th }}$ and $16^{\text {th }}$ regnal years. The dates as given in the text are the corrected ones; they follow the most common custom of the London Chronicles and of Stow's Summary, in accordance with which the first mayoral year of Henry VIII was that of the mayor, who took office on $29^{\text {th }}$ October 1509.

The second Chronicle for 1548-55 is distinguished from the first by its much greater fulness in matters which it describes, and by less attention to trivial incidents. Partly for these reasons, and

1 Holinshed, iii. 793, 798, 803, 810 ; cf. pp. Io, 13, I5 below.

${ }^{2}$ pp. 8-9.

${ }^{3}$ p. II-I2.

'p. 15 .

5 p. I. 
partly because Stow, from whatever cause, made much less use of it, it is of far more interest. Stow had by this point reached a time well within his own recollection, and may consequently have depended less on written memorials. When he first wrote, moreover, events of such recent happening required discreet handling. When later on he expanded his history, he had at his disposal the manuscript Chronicle of Queen Fane and Queen Marie', and also as it would appear a copy of Charles Wriothesley's Chronicle. Thus he not only made less use of our Chronicle from 1548 to 1555 in his Summary, but also omitted more of what he had at first borrowed, when he came to write his Annales.

The Chronicle opens with a long account of the disturbances of 1549. The description of the rising at Exeter is followed fairly closely by Stow. The story of the disparking of Thame and Rycote, as here given, seems to be novel, and the account of Kett's rebellion differs from that given by Stow. ${ }^{2}$ The first arrest of Somerset, ${ }^{3}$ and the story of Captains Charles and Gambold, ${ }^{4}$ are given without any particular additions to other accounts. Most of the history of $1550-52$ appears in a very similar form to that adopted by Stow in his Summary. ${ }^{5}$ Of the events which attended the accession of Queen Mary we get an independent and interesting account of which Stow made little use. ${ }^{6}$ Wyatt's rebellion is described freshly, as by one who wrote from his own knowledge; the most notable new point being the story of how Wyatt managed to get into Fleet Street without being recognised. ${ }^{7}$ There is a good deal of detail on the subsequent incidents of the spring of 1554 , but with nothing that calls for comment till we reach the trial of Nicholas Throckmorton, ${ }^{8}$ where the sufferings of the stalwart jurors, who would not find him guilty, are told at more length than elsewhere. The arrival of Philip of Spain is described with

${ }^{1}$ Harley MS. 194: printed in Camden Society It Series No. 48.

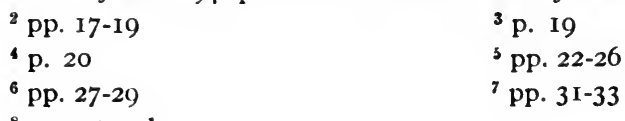

${ }^{8}$ pp. 35 and 39 
some small details of interest. ' Gardiner's sermon at Paul's Cross on $2^{\text {nd }}$ December, $1554,{ }^{2}$ is summarised in a manner which shows that the Chronicle consists of notes, perhaps written down on the spot, until the bells ' made such noise that I could not understand three words together.' Of this, the most interesting passage in the whole Chronicle, Stow made no use at all. So far as I can discover no other writer gives so minute an account of Gardiner's sermon. The Chronicle ends with the death of Gardiner in November, 1555. But the history of the last eleven months includes nothing of importance, which cannot be found elsewhere. The description of the flood in October, $1555,{ }^{3}$ shows how Stow used this Chronicle in his Summary, but discarded it in the Annales. The use of the Chronicle by Stow, and the points in which it differs from other contemporary records are illustrated sufficiently in the footnotes to the text. Except where otherwise noted the Summary is quoted from the edition of 1566 (which here differs little from that of 1565), and the Annales from the edition of 1605 . (Stow's own final and anthoritative text).

The brief City Chronicle for 1547 to 1564 is of a different character to the previous one. Harley MS. $530 \mathrm{ff}$. 105-110, whence it comes, consists of short historical notes written early in the reign of Elizabeth. The first note is for the 54th year of Henry III taken from Fabyan. Other notes of fourteenth century history follow from Froissart. A notice of Wiclif is borrowed from John Bale. On f. 107 comes a note, which is worth quoting as a characteristic specimen :-

"Mr. Hall writeth the batayle of Egyncorte to be in the 4 yere, $\&$ I do think it gode to referr the redar to $\mathrm{m}^{\text {tr }}$ hall, who writeth of it at large takyn owt of the frenche cronicle made by enguyron, ${ }^{4}$ who did write ymmediatly after frosard."

\footnotetext{
${ }^{1}$ pp. $37-38$

3 p. 43
}

${ }^{2}$ pp. 40, 4I

- Enguerrant de Monstrelet. 
On $\mathrm{f} .108^{\text {ro }}$ there are a few notes on the reign of Henry VIII. The last alone is of any interest :-

"In the 25 yere the statute was made for the selling of flessh by waight ; toke effect the first day of August." "

There then begins the more regular and original Chronicle here printed. "The writer, unlike the authors of the previous Chronicle, seems from his notices on religious matters to have been a Protestant. There are a few entries of political matters. But the more interesting part of the Chronicle consist of notes, which would appear to have been made by a London merchant trading abroad. They relate chiefly to incidents and disasters at sea : to captures of French and Spanish ships : to the pirate Strangwysh'; and to the naval warfare off Newhaven, or Havre, in 1563-64. The reference to an exploit of John Hawkins in the autumn of 1563 seems to be novel. Other entries on the rate of exchange with Antwerp, and on prices, also indicate that the writer was interested in commerce. Two amusing notes are of the rainy season of 1563, which caused such a dearth of hops that beer was brewed with broom and bay-berries, and of the abundance of fruit in the following summer. The statement as to the causes which led to the English intervention at Havre in 1563, appears to have been borrowed by Stow for his own narrative in the Annales.

Apart from its contents this Chronicle has a certain interest as illustrating how long the practice of keeping written records in the form of civic Annals persisted with London citizens.

1 Cf. Stow, Survey of London, i. I87.

2 pp. 47-49. 


\section{A LONDON CHRONICLE}

\section{I $523-1555$}

The notes folowynge wer copied out of Myst'. Lordynges boke.

$$
\text { Richard } y^{\mathrm{e}} \text { seconde }
$$

The iijde yere of his reygne $y^{\mathrm{e}}$ galyottis of Spayne $\mathrm{w}^{\mathrm{t}}$ othar small shipps cam a land at Gravesende, \& robbyd \& brent $\mathrm{y}^{\mathrm{e}}$ moaste parte $\left[\right.$ of $\left.\mathrm{y}^{\mathrm{e}}\right]$ towne.

The xviij. yere of Richard $y^{e}$ second $y^{e}$ heresies of John Wykclyffe began to spryng in England.

\section{Henry $y^{e}$ fourthe}

$\mathrm{Y}^{\mathrm{e}} \mathrm{xj}$. yere of his reygne began $\mathrm{y}^{\mathrm{e}}$ alaye of goulde : \& $\mathrm{y}^{\mathrm{e}} \mathrm{kyngs}$ sons betyn in $\mathrm{y}^{\mathrm{e}}$ Chepe.

$$
\text { Henry } y^{e} \text { vij }
$$

The first yere of his reyne $\mathrm{y}^{\mathrm{e}}$ crosse in Chepe was new buylded, Hughe Bryce beyng mayre.

The xiij of his reygne $y^{\mathrm{e}}$ wedercoke of Powlls was new made.

$$
\text { Henrie } y^{\mathrm{e}} \text { viij }
$$

This boke dothe accowmpte $\mathrm{y}^{\mathrm{e}}$ yere to begyn at November, but yt dothe not begyn tyll Aprill next foloynge, which is to be noted. ${ }^{1}$

1 This is a note made by Stow, who did not then realise that these London Chronicles were dated by mayoral years beginning on $29^{\text {th }}$ Oct. The regnal years of Henry viii began on $22^{\text {nd }}$ April. See Introduction, p. iii. above. 
$\mathrm{Y}^{\mathrm{e}} \mathrm{xv}$. yere of Henrie $\mathrm{y}^{\mathrm{e}}$ viij, Tomas Baldry beyng mayre, was $\mathrm{y}^{\mathrm{e}}$ lady Hungarford and hir man hangyd at Tyburne. ${ }^{1}$

- The xvj. yere of his reyne $\mathrm{y}^{\mathrm{e}}$ castell of Grenewyche was buyldyd. $\mathrm{Y}^{\mathrm{e}}$ same yere, $\mathrm{y}^{\mathrm{e}} \mathrm{xviij}$ daye of June, was creatyd at Brydewell Henrie, $y^{\mathrm{e}}$ kyngis bastard, duke of Richemont \& Somersete, \& earle of Nothyngham, highe steward of Englande, warden of all $y^{\mathbf{e}}$ marches agaynst Scotlande, hyghe admyrall of $y^{e}$ sea, highe Justice of all $\mathrm{y}^{\mathrm{e}}$ kyngs parkes, chaces, mayrynes, \& forestis from Trent to Scotland, \& hyghe steward to $\mathrm{y}^{\mathrm{e}}$ byshope of Yorke \& Doram. ${ }^{2}$

The $x$ vij. yere of his reygne, $y^{e} x j$. day of februarie, beynge shroffe sondaye, v. men of $y^{\text {e }}$ Stilaard dyd penaunce, iij. of them bare fagotes at Powles, \& ij. of them bare taperes. And an awsten fryar callyd doctor Barns of Cambryge bare a fagot at Powles $y^{\mathbf{e}}$ same daye. The same yere $\mathrm{y}^{\mathrm{e}} \mathrm{vj}$. day of September was proclamyd of goulde $y^{e}$ frenche crowne iiij.s. vj.d., $y^{\mathrm{e}}$ halffe noble iij.s. ix.d., $y^{e}$ angell noble vij.s. vj.d., and $y^{\mathrm{e}}$ riall xj.s. iij.d., \& so every pese affter $\mathrm{y}^{\mathrm{t}}$-alewe. ${ }^{3}$

The $\mathrm{x}$ viij. yere, Thomas Seamar mayre, of his reygne, $\mathrm{y}^{\mathrm{e}} \mathrm{ijj}$. day of Julii, $y^{\mathrm{e}}$ lorde cardenall rode thorowe Chepe, \& so toward Fraunce $^{4} ; \& y^{\mathrm{e}} \mathrm{xv}$. day of $\mathrm{y}^{\mathrm{e}}$ same monythe was one Harman drawyn from Newgate to Tyburn, \& there hangyd for qwynynge of falce golde. ${ }^{5}$ And in $y^{-e}$ same yere in Julii \& in August was $y^{e}$ slewcys made in Fynsbery fylde to convaye ye yll watars ovar $y^{\mathrm{e}}$ towne dyche by pypes of lede in to $y^{\mathrm{e}}$ Temes. ${ }^{6}$ In $y^{e}$ same yere was great skarsnes of breade at London, \& all England, $y^{t}$ many dyed for defaut therof : $\& y^{\mathrm{e}}$ bread cartes $\mathrm{y}^{\mathrm{t}}$ came from Stratford to London were mett by $\mathrm{y}^{\mathrm{e}}$ way at Myll ende by $\mathrm{y}^{\mathrm{e}}$ citisens of London,

1 The notice for this year is added in the margin.

2 Summary omits.

3 This forms the whole notice for the year in the Summary, save for an addition as to the sermon preached by bishop Fisher at $S^{t}$ Paul's on II $^{\text {th }}$ Feb.

4 At more length in Summary.

5 Summary, but reading: 'coynynge'.

6 Abbreviated in Summary, and in Survey, ii. 77. 
$\mathrm{y}^{\mathrm{t}} \mathrm{y}^{\mathrm{e}}$ mayr and shrivis were fayne to goo \& reskew them, \& se them browght to $\mathrm{y}^{\mathrm{e}}$ markytis apoyntyd. ${ }^{1}$

The xix. yere, of his reygne, James Spencer mayre, $y^{\mathrm{e}}$ first day of Novembar, my lord cardinall $\mathrm{w}^{\mathrm{t}} \mathrm{y}^{\mathrm{e}}$ Ambasadours of Fraunce wer at Powles, \& ther was proclaymyd a generall peace betwene kyng Henrie of England \& Francys $y^{\mathrm{e}}$ frenche kynge durynge theyr lyves, \& a xij. monythe \& a day afftar. ${ }^{2}$

The viij. day of Novembar iij. scolers of Cambryge, $\&$ one Fostar a gentyllman of $\mathrm{y}^{\mathrm{e}}$ cowrte bare ffagotts at Powlis for heresy. ${ }^{3}$

This yere was no watche at mydsomer. $y^{\text {e }}$ vij. of October cam to London a legat from Rome.

The v. day of January $\mathrm{y}^{\mathrm{e}}$ cardynall, \& many byshopes, \& abbotis, $\&$ priours, went a prossecion at Powles, \& sange te deum for $\mathrm{y}^{\mathrm{e}}$ eskapynge of $\mathrm{y}^{\mathrm{e}}$ pope from $\mathrm{y}^{\mathrm{e}}$ emperour.

The xiij. day of January was a great fyar at Andrewe Moreys key in Tems strete, \& anothar key by it, wher was myche hurte done. The vij. day of Aprell $y^{\mathrm{e}}$ lord master of $\mathrm{y}^{\mathrm{e}}$ Rodes cam to London, $\&$ lay at sent Johns in Smythfyld. The xvij day of June $y^{e}$ terem was aiournycl to myhellmas aftar, becaws of $y^{\mathrm{e}}$ swetynge sykenes $\mathrm{y}^{\mathrm{t}}$ reygnyd at $\mathrm{y}^{\mathrm{t}}$ tym in London \& in othar placis. ${ }^{5}$

The $\mathrm{xx}$. yere of his reygne, J. Rudstone mayre, $\mathrm{y}^{\mathrm{e}} \mathrm{xxix}$. of November $\mathrm{y}^{\mathrm{e}}$ parysshe prist of Hony lane \& a yonge man, $\mathrm{y}^{\mathrm{t}}$ some tyme was vsshar of seynt Anthonys scole, bare fagottis at Powlis. And ij. othar men, one a duche man, $y^{\mathrm{e}}$ othar an englyshe man, bare tapers of wax for sellyng of Martyn Leuthars bokes. ${ }^{6}$

The viij. daye of Maye a powche maker bare a fagote at Powles

1 Summary with additions from Hall.

2 Summary.

3 Summary.

4 Because of the sweating sickness. This and the following note are transferred in the Summary to their proper chronological position at the end of the year.

5 The whole of this paragraph appears in the Summary, with the addition of a note as to how two French and Flemish vessels chased one another from Margate to Tower wharf.

6 Summary, but omitting, 'for sellyng etc.' A note on the sessions of the Cardinals at Blackfriars is then inserted from Hall. 
for heresye. The vj. day of September one John Skotte, wodmonger, dyd penaunce in Chepe and othar placis of $y^{e}$ citie, goynge in his shurte, bare leggyd \& bare fottyd, and a proclamacion made at $y^{\mathrm{e}}$ Standard, at Ledyn hall, \& at Grace churche vpon misdemeanor agaynst $\mathrm{y}^{\mathrm{e}}$ mayre $\& \mathrm{y}^{\mathrm{e}}$ aldermen $\mathrm{w}^{\mathrm{t}} \mathrm{y}^{\mathrm{e}}$ shrives. ${ }^{1}$

The xviij. day of October was $y^{e}$ cardynall dyschargyd of his chauncelourshype, $\& y^{\mathrm{e}}$ kynge seasyd all his goods $\&$ his place at Westmystar : \& $y^{\mathrm{e}} \mathrm{xxv}$. day of $\mathrm{y}^{\mathrm{e}}$ same monythe he went from Yorke place to Ashehere ${ }^{2} \mathrm{w}^{\mathrm{t}} \mathrm{xxx}$. persones \& no more, \& ther to abyde tyll he knew furdar of $y^{\mathrm{e}}$ kyngs pleasure. And the xxvj. day of Octobre was sir Thomas More made chauncelour of England, \& sworne, \& kepte his rome all one day. ${ }^{3}$

The xxj. yere of his reygne, Rauffe Dodmer mayre, ye viij. day of Decembre was one sir Thomas Bolyn, callyd lord of Rocheforde, was made earle of Ormonde $\&$ of Wylshere, \& ye lorde ffughe Watars ${ }^{4}$ was made earle of Sussex, \& my lorde Hastynges was made earle of Huntyngton. ${ }^{5}$ The xiij day of Janewarie was a great fyar in $y^{e}$ Vyntry, \& myche hurte done. The xxiij. day of Janewarie was iij. men, one a Gaskone, \& ij. eryche ${ }^{6}$ men, drawne from Newgat to $\mathrm{y}^{\mathrm{e}}$ Towerhyll, and ther hangyd \& quarteryd for countarfeytynge $y^{\mathrm{e}}$ kyngs coyne. The $\mathrm{xvj}$. day of Maye was a gebyt set $\mathrm{vp}$ in Fynsbery filcle, \& a man hangyd in chaynes for kyllynge of doctour Myles, vykar of sent Brydes. The v. day of Julii was one hangyd in chayns in Fynsbery fyld for kyllynge mastres knevytt's mayd in sente Auntolyns paryshe. ${ }^{7}$

The xxij. yere of his reygne, Thomas Pargetour mayre, $y^{\mathrm{e}} \mathrm{xix}$.

' Summary, but reading: ' his demeanor'.

2 Esher.

${ }^{3}$ Summary. Three notes are then added on William Tyndale, the peace, and the parliament at Blackfriars.

4 Fitz Walter.

5 The notice of these creations is omitted in the Summary.

6 Irish.

7 The whole of the latter part of this paragraph appears in the Summary, together with two notes on Tyndal's translation of the New Testament, and on the proclamation prohibiting communication with Rome. 
day of Novembar iiij. men, whose names were, Thomas Somar, John Pursar, Tyndall, \& a prentys on London brydge, they rode from the Towre of London $\mathrm{w}^{\mathrm{t}}$ papars on theyr heades vnto $\mathrm{y}^{\mathrm{e}}$ crosse in Chepe, \& ther was made a great fyar $\&$ theyr bokes brent. $^{1}$ The v. day of Aprylle was a coke boylyd in a cawdren of brasse in Smythefylde for $\mathrm{y}^{\mathrm{e}}$ poysonynge of $\mathrm{y}^{\mathrm{e}}$ byshope of Rochestars servant. ${ }^{2}$ At mydsomar $y^{\mathrm{e}}$ constables rode in $\mathrm{y}^{\mathrm{e}}$ watche. The xiiij. day of Julii maystre Lacis servant was hangyd in Fynsbery fylde for $\mathrm{y}^{\mathrm{e}}$ morderynge of a mayde, $\&$ for $\mathrm{y}^{\mathrm{e}}$ robynge of this sayd mistar Lacie.

The xix. day of August $y^{\mathrm{e}}$ byshope of Norwyche brynt a master of Arte callyd Thomas Bylneye. The xxij. day of October Paytmer, a merchant \& a glayssyar, bare fagotis at Powles. ${ }^{4}$

The xxiij. yere of his reygne, Nicholas Lambarde, mayre, $y^{\mathrm{e}} \mathrm{v}$. day of November ij. men bare fagotis at Powles, one of them was Parnylls servant, a drapar. The $\mathrm{xj}$. day of Novembar Harie Thomson was commyttyd to perpetuall pryson for eresye: the same Harie cam owt agayn by $\mathrm{y}^{\mathrm{e}}$ kyngs chartar : $\mathrm{y}^{\mathrm{e}}$ same day on Pattmer, a pryst, was commyttyd to pepetuall pryson for heresye. ${ }^{5}$ The xxvij. day of November was a monke of Bery ${ }^{6}$ burnt in Smythefylde for heresie. ${ }^{7}$ The iiij. day of December was one Risse ${ }^{8}$ Gryffyn, a gentylman of Wales, behedyd at $y^{\mathrm{e}}$ Towre hyll, $\&$ his man hanged, drawne, \& quarteryd at Tybourne for treason. The xx. day of Decembar was a pouchemaker brent in Smythefyld for heresie. ${ }^{9}$ The xxvij. day of Janewarie, a douche man bare a

1 Omitted in Summary.

2 Summary, but reading: 'poysonynge dyuers persons at the byshop of Rochesters place '; and giving the cook's name 'one Richarde Rose'.

3 These two notes are omitted in the Summary.

4 Summary; but Bilney is called 'a bacheler of law', and 'Paules crosse' is substituted for 'Powles'.

5 These notes are omitted in the Summary.

6 Bury.

7 Summary omits 'for heresie'.

8 Ryce, Summary.

9 Summary omits this note. 
fagot at Powles crosse for heresie. Y'e $\mathrm{xj}$. day of February one bare a fagot at Polls crosse. The xxj. day of August one bare a fagot at Powlys for heresye. ' The laste day of Apryll was one Baynam brent in smythefylde for herisye. The xxi. day of Maye was takyn between Grenewyche \& Lonclon ij. greate fyshis callid herlpoles, both a male \& a female. The iiij. clay of June was dyscharged syr Thomas More of his chancelourshipe, $\&$ for him was chosyn mistar Audleye, sergant of $y^{\mathrm{e}}$ coyffe, \& was made cheffe justice in $y^{\mathrm{e}}$ chancerie, \& cald hy his offyce lorde brode seale. ${ }^{2}$ The $\mathrm{xr}$. day of June was v. men drawne from Newgate to $\mathrm{y}^{\mathrm{e}}$ Towr hyll, \& then hangyd \& quarteryd for qwynynge of sylvar \& clypynge of gowld. ${ }^{3}$ The xxviij. clay of June was one othar man hangyd in chaynes in Fyusbery fylde for $y^{\mathrm{e}}$ kylynge of mystris Lacis mayd. " The v. day of Julii was a pryst dwellynge at S. Andrews by syd ye wardrope drawne from Newgate to $y^{\mathrm{e}}$ Towr hyll, \& ther hangid \& quarteryd for clypynge of gowlde. ${ }^{5}$ Allso in Julii $y^{\text {e }}$ kynge put downe $y^{\text {ee }}$ priour of Christchurche in London, all $\mathrm{y}^{\mathrm{e}}$ chanons of $\mathrm{y}^{\mathrm{c}}$ same place $\mathrm{y}^{\mathrm{e}} \mathrm{kyng}$ sent to othar placis of $\mathrm{y}^{\mathrm{e}}$ same relygyon, for be caws $y^{\prime \prime}$ same priour lyryd vinthriftely \& $\mathbf{w}^{\mathrm{t}}$ his vngracious rewle brought $y^{\text {e. }}$ same house in lebt, $y^{t}$ he was not able to kepe his housse and mayntayne it. ${ }^{6}$ The xvij. day of Auguste ij. prestis of Allhallows in Bredstrete fell at variance, $y^{t} y^{e}$ one prist drew blode on $y^{\text {e }}$ othar, wherfore $y^{\text {-e }}$ same churche was supendyd \& and no servys sayd nor songe in one monythe. This yere in August \& Septembar $y^{\text {e }}$ kynge repayryd $y^{\mathrm{e}}$ Towr of London, \& mad ther myche buyldynge. The fyrst of Septembar

1 Summary omits the last two notes.

2 Stow records this in his own words, and adds notes on the king's supremacy, and on Cromwell's promotion.

${ }^{3}$ Summary, but reading: ' coynyng'.

4 Summary onits.

- Summarex.

6 Summary, but omitting from ' for be caws' to 'mayntayne it.' Compare Stow's story of the prior's hospitality ap. Survey i. I4I and ii. 29I, and Hall, Chronicle.

7 Given with the subsequent note of their penance by Stow in Suriey, i. 347. 
was the lady Anne Bullyn made marchionys of Penbroke at Wyndsore. The vij. clay of October $\mathrm{y}^{\mathrm{e}}$ kynge went to Calys \& to Bol1yne, \& came ovar agayn $y^{\mathrm{e}}$ xiij. day of Novembar folowynge. ${ }^{1}$ The xxv. day of Octobar $\mathrm{y}^{\mathrm{e}} \mathrm{ij}$. pristis of Allhallowne in Bredstrete wer joynyd in penaunce to go byfore $y^{\mathrm{e}}$ generall prossecion $\mathrm{w}^{\mathrm{t}}$ bare feet, bare leggyd, \& bare hedyd, before $\mathrm{y}^{\mathrm{e}}$ children, ${ }^{\mathrm{t}}$ bedes $\&$ bokes in theyr hands, \& so dyd theyr penaunce.

The xxiiij. yere of his reygne, Stephen Pelioke, mayre, $\mathrm{y}^{\mathrm{e}} \mathrm{xv}$. day of Decembar was a great fyar at $y^{\mathrm{e}}$ byshop of Lyncolnes place in Holbourne, \& myche hurt done. ${ }^{2}$

The xvij. day of Marche was chosyn Edward Hall, gentylman, of Greys In, to be comon sargaunte of $\mathrm{y}^{\mathrm{e}}$ citie of London. ${ }^{3}$ The $\mathrm{x}$. day of Aprill was a dole at sent Mary Overies in Sothewarke, \& at $\mathrm{y}^{\mathrm{e}}$ same dole was so great preace of pore people $\mathrm{y}^{\mathrm{t}}$ ther was smoulderyd in $\mathrm{y}^{\mathrm{e}}$ strete iiij. men, ij. wemen, \& a boye, starke deade. ${ }^{4}$ The xij. day of Aprill was ye countes of Pcnbroke, lady Anne Bolyne, dowghter of syr Thomas Bolen, bacheylar knyght, but $\mathrm{y}^{\mathrm{e}}$ kynge made hym lorde of Rocheforde, \& earl of Wylshire $\&$ Ormonde, on Estar eve $\mathrm{y}^{\mathrm{e}} \mathrm{xij}$. day of Aprill she was proclaymyd quen of England; \& quene Katheryn was put downe, \& hir dowghtar Mary, pryncis, was lykewyse put downe, beyng his owne dowghtar gotyn on quene Katheryn, whiche was xxiiij. yere his wyffe \& quene of England, a blysyd lady \& a good. " $\mathrm{Y}^{\mathrm{e}}$ xij. day of May Pavyar, $y^{e}$ towne clarke, honge hym selffe. The iiij. day of Julii was brent in Smythefyld John Frythe, a scolar of Oxforde, \& a taylours servante, bothe together for heresye. ${ }^{6}$ The vj. day of Julye was quen Katheryn proclaymyd princis Arthours

1 The last three notes in Summary, with an addition on the king's marriage to Anne Boleyn.

2 Summary.

3 Summary adding: "Whiche Edward Halle made the notable boke of Chronicles'.

4 Summary but reading, 'Audries ' for ' Overies ', and omitting 'in ye strete'.

5 For the proclamation of Queen Anne the Summary follows Hall's Chronicle, and omits the reference to Queen Katharine altogether.

6 Wriothesley's Chron. i. 22. The second was Andrew Hewit. 
Wydowe. ${ }^{1}$ The xvij. day of Julii were $\mathrm{ij}$. marchauntis slayne on $\mathrm{y}^{\mathrm{e}}$ watar toward Westmynstar by one Wolffe $\&$ his wyffe. The xxiij. day of August wear ij. women betton abowght the Chepe nakyd from $\mathrm{y}^{\mathrm{e}}$ waste vpwarde, $\mathrm{w}^{\mathrm{t}}$ roddes, \& theyr eris naylyd to $\mathrm{y}^{\mathrm{e}}$ Standard for bycause they sayd quene Katheryn was $\mathrm{y}^{\mathrm{e}}$ treu quen of England, \& not quene Ane: and one of $\mathrm{y}^{\mathrm{e}}$ wemen was byge $\mathrm{w}^{\mathrm{t}}$ childe : \& whan thes $\mathrm{ij}$. wemen had thus bene punyshed, they forteffyed theyr sayenge styll, to dy in $y^{\mathrm{e}}$ quarell for quene Katheryns sake. ${ }^{2}$ The v. day of Octobar was a great fyar at Baynards castell, \& great hurt don.

The xxv. yere of his reygne, Christopher Askewe, mayre, $\mathrm{y}^{\mathrm{e}}$ xxiiij. day of Octobar was ther a skafolde set up at Powles crosse, $\&$ ther on stode a none namyd Anne ${ }^{3}$ Barton, callyd $y^{e}$ holy mayd of Courtopstrete ${ }^{4}$ bysyde Cauntourbury in Kent, \& ij. monkes of Cauntourbery, $\mathrm{y}^{\mathrm{e}}$ one was doctor Boccynge, a devyn, \& ij. obsarvant fryars, one was $y^{\mathrm{e}}$ father of $\mathrm{y}^{\mathrm{e}}$ house of Richemount $\& \mathrm{y}^{\mathrm{e}}$ othar was of Cauntourbery, $\& \mathrm{y}^{\mathrm{e}}$ parson of Aldermary in London callyd Mst. Gowlde, \& anothar priste confessor to $\mathrm{y}^{\mathrm{e}}$ same none, $\&$ ij. lay men, $\&$ at $\mathrm{y}^{\mathrm{e}}$ same crosse was a sermond made by $\mathrm{y}^{\mathrm{e}}$ byshope of Bangowre, callyd $\mathrm{y}^{\mathrm{e}}$ Abbot of Hyde, wher was shewyd all theyr offencis, \& so they wer from thence removyd to $\mathrm{y}^{\mathrm{e}}$ Towr. ${ }^{5}$

1 The Summary omits the last two notes. It gives the enactment for butchers, which reappears in the Survcy, i. 187 .

2 This pathetic story is omitted in the Summary. It is remarkable that the Chronicle has no notice of the birth of Elizabeth on 7 Sept, which Stow duly inserts before the note on the fire at Baynard's Castle.

${ }^{3}$ Should be 'Elizabeth'.

4 Court-up-street, or Court-at-street.

${ }^{5}$ In the Summary Stow transiers this verbatim to the $24^{\text {th }}$ mayoral year, to which it properly belongs. The true date was $23^{\text {rd }}$ Oct. see Letters and Papers vi. 1433,1460 and vii. 72 , p. 29, and Gairdner, Lollardy and the Reformation, i. 455 . Wriothesley Chron. i. 23 gives the date as $23^{\text {rd }}$ Nov. The monks were Edward Bockyng and Richard Deryng, the friars Hugh Rich and Richard Risby, the priest Richard Masters, parson of Aldington, and the laymen Edward Thwaytes and Thomas Gold. 
The xxviij. day of Januarie was a great fyshe taken at Blake walle callyd a whall, \& was brought up to Westminstar to $\mathrm{y}^{\mathrm{e}}$ kynge to see, so browght downe to Broken wharffe \& ther cut out.

The fyrst day of Apryll wer Wolffe $\&$ his wyffe hangyd at $y^{e}$ turnynge tre in Lambethe marche, for $y^{\mathrm{e}}$ deathe of $\mathrm{y}^{\mathrm{e}} \mathrm{ij}$. Lombardes afore namyd. The xx. day of Apryll were ij. monkes of Cantorbury, ij. observant fryars, $y^{\mathrm{e}}$ person of Aldermarie in London, \& a none callyd $\mathrm{y}^{\mathrm{e}}$ holy mayd of Courthopstrete in Kent bysyd Cauntourbery, all thes wer drawne from $y^{\mathrm{e}}$ Tour of London vnto Tybourne \& ther hangyd, qwarteryd, \& theyr hedes set vpon London brydge, $\&$ at $y^{\mathrm{e}}$ gate of $\mathrm{y}^{\mathrm{e}}$ citie of London. ${ }^{1}$ The $\mathrm{xx}$. day of Apryll all $\mathrm{y}^{\mathrm{e}}$ craftes \& companyes in London were sworne to $\mathrm{y}^{\mathrm{e}}$ kynge $\&$ to quene Anne $\&$ theyr eyres. The xxv. day of Maye was a great fyar at $y^{\mathrm{e}}$ Saltars hall in Bredstrete $\&$ moche harme done. The v, day of June wer all servants $\&$ prentisys of $\mathrm{y}^{\mathrm{e}}$ age of $\mathrm{xx}$. yeres or above sworne to $\mathrm{y}^{\mathrm{e}}$ kynge, \& quene Anne his wyffe, $\&$ to the issewe of them. The ix. day of Julii was $y^{\mathrm{e}}$ lord Dacres of $y^{\mathrm{e}}$ northe araynyd of treason, and acqwyted of $\mathrm{y}^{\mathrm{e}}$ same. ${ }^{2}$

The xj. day of August was all $\mathrm{y}^{\mathrm{e}}$ placis of $\mathrm{y}^{\mathrm{e}}$ obsarvant fryars, as Grenewyche, Cantorburie, Rychemonte, \& Newarke, \& Newcastell, put downe, \& Austyn fryars put in $\mathrm{y}^{\mathrm{e}}$ same places, \& $\mathrm{y}^{\mathrm{e}}$ same obsarvantis wer put in placys of graye fryars \&c. The xiij. day of August was a great fyar at $\mathrm{y}^{\mathrm{e}}$ Temple barr, \& myche hurt don \& certayne persons byrnt. The xv. day of August ye kyngs place at Charynge crosse, callyd $y^{e}$ Mewse, was a fyre. ${ }^{3}$ The $x x j$. day of Septembar doctor Taylor, mastar of $y^{\mathrm{e}}$ Rolls was dyschargyd, $\&$ for hym Mst. Thomas Cromwell was made maystar of $y^{\mathrm{e}}$ Rolls, $\&$ sworne $\mathrm{y}^{\mathrm{e}} \mathrm{ix}$. day of Octobar. ${ }^{4}$

1 Summary adds : 'and theyr bodies buried'.

"Summary has 'treason, where he so wittily and directly confuted hys accusers, that to theyr great shame, he was founde by his peres not gyltie '. Stow then inserts from Hall a notice (misplaced, see above under $1532-33$ ) of the martyrdom of John Frith and Andrew Hewet.

3 This is differently described in the Summary.

4 Summary adds : ' who afterwarde bare great rule.' 
The xxvj. yere of his reygne, John Champneys mayre, ${ }^{1} \mathrm{y}^{\mathrm{e}} \mathrm{xxix}$. day of Apryll $\mathrm{y}^{\mathrm{e}}$ prior of $\mathrm{y}^{\mathrm{e}}$ Charterhouse of London, the prior of Beuall, ${ }^{2}$ the prior of Exsam, ${ }^{3} \&$ a brodar of $y^{\mathrm{e}}$ same callyd mistar Raynolds, \& a pryste callyd Mast. John Hayle, vicar of Thystylworthe ${ }^{4}$ were all condemnyd of treason \& judgyde at Westmystar to be drawne, hangyd, \& quarteryd at Tybourne, who wer executyd at Tyborne $y^{\mathrm{e}}$ iij. day of May. \& ther heds \& quarters set at every gate of Lonclon, \& at $\mathrm{y}^{\mathrm{e}}$ Chartarhous in London one quartar. The viij. clay of May the kynge comaundyd all about his court to powl theyr hedes, \& to gyve them ensample he dyd cawse his owne hed to be powllycl lykewyse. The xxv. day of May was a great examynacion of erytykes borne in Holand beyond $y^{e}$ see; ther was eximynycl xix. men $\&$ vj. wemen of $y^{\mathrm{e}}$ same country borne. 'The ij. clay of June mistar Hall was chosyn vnclar shrive by $y^{n}$ mayre \& comon counsell, who was before $y^{\text {e }}$ comon sargante of Lonclon. ${ }^{6}$ The iiij. clay of June a man \& his wyffe borne in Bothe in Holand ${ }^{7}$ wer byrnt in Smythefyld for heresye. ${ }^{8}$ The xviij. clay of June wer thre monkes of $y^{\mathrm{e}}$ Chartarhouse, Exmew, Mydilemor, \& Nydygate, drawn to Tyborne, \& ther hangyd \& quarterycl. The xxij. clay of June was doctor Fyshar, byshope of Rochestar, behedyd at $\mathrm{y}^{\mathrm{e}}$ Towre hyll, ${ }^{9}$ [his body buryed at Barkynge $\left.{ }^{10}\right]$. The xvj. clay of Julii syr Thomas More was behedyd at

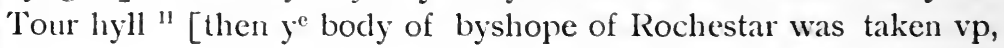

1 In the Summary Stow inserts a note on the Parliament of November, 1534.

9 Beauvale.

3 Summary reads 'Hexham'. It should be 'Axholme'.

4 Isleworth.

5 Summary then adds "their opinions".

6 Summary adds : 'as is aforesaid.'

7 Summary: "borne in Holland'.

s Summary: 'for the Arrianes heresie'.

9 Summary inserts: 'his head was set on London bridge, and '.

10 Allhallows Barking.

11 Summary inserts: 'for denyall of the Kynges supremacy', and omits the following clause. The words bracketed above are an insertion, and perhaps did not appear in the original. In the Annales, 963. Stow follows the Chronicle, as 
$\& w^{t} y^{e}$ body of $s$. Thomas More buryd in $y^{e}$ Towre]. ${ }^{1}$ In October $\mathrm{y}^{\mathrm{e}}$ kynge sent doctour Lee to vysyt $\mathrm{y}^{\mathrm{c}}$ abayes, priories, \& nonryes in England, \& to put out all relygious persons that wolde goo, $\&$ all them $y^{\mathrm{t}}$ wer vnclar $\mathrm{y}^{\mathrm{e}}$ age of $\mathrm{xxiiij}$. yers, as nones, fryars, monkes, \& chanons, $y^{\mathrm{e}}$ were put of theyr housys, $\mathrm{y}^{\mathrm{t}}$ abot \& pryor shulde gyve every one in $\mathrm{y}^{\mathrm{e}}$ stecle of ther abbet a pristes gowne, $\&$ xl. s. of money, \& $y^{\mathrm{e}}$ nunes to have suche aparell as seculer wemen were, \& to go wher they wyll. He toke out of monestaries $\&$ abbayes all theyr relikes \& jewells ${ }^{2}$

Syr John Allyn, mayre, $y^{\mathrm{e}} \mathrm{xxvij.}{ }^{3}$ yere of $\mathrm{y}^{\mathrm{e}}$ kynge, $\mathrm{y}^{\mathrm{e}} \mathrm{xj}$. day of Novembar, beyng styll in $y^{e}$ xxvij. yere of Henrie $y^{e}$ viij., was a great procession at London by $\mathrm{y}^{\mathrm{e}}$ kyngis commandement : fyrst went $\mathrm{y}^{\mathrm{e}}$ wayts of $\mathrm{y}^{\mathrm{e}}$ citie all $\mathrm{vj} .,{ }^{4} \&$ nexte folowynge $\mathrm{y}^{\mathrm{e}}$ children of $y^{e}$ gramer scoll of sente Thomas of Acres $w^{t} y^{e}$ schollmayster afftar them $;{ }^{5}$ next aftar them came sent Anthonys scole \& $y^{\mathrm{e}}$ mastar $\&$ vshar aftar them : nexte came $\mathrm{y}^{\mathrm{e}}$ scholars of Powles schole $\mathrm{w}^{\mathrm{t}}$ theyr mastar \& vshar aftar them : next came all $y^{\mathrm{e}}$ mynstrells of London in theyr best apayrell, \& $y^{\mathrm{e}}$ mastar of $y^{\mathrm{e}}$ sayd mynstrells $w^{\mathrm{t}}$ his gyrdyll abought hem as he doth were on myd lent sondaye : ${ }^{6}$ nexte aftar them com $y^{\mathrm{e}}$ crwchyd fryers, \& every fryer had a coppe and theyr crosse : nexte aftar them com $y^{\mathrm{e}}$ fryars Austyns $w^{\mathrm{t}}$ theyr crosse \& every fryar a cope : next came $y^{\mathrm{e}}$ white friars $w^{\mathrm{t}}$ theyr crosse \& every friar a cope : next came $y^{\mathrm{e}}$ grayc fryars \& theyr crosse \& every fryar a cope : next came $y^{\mathrm{e}}$ blake fryars $w^{\mathrm{t}}$ theyr crosse \& every fryar a cope, syngynge $y^{\mathrm{e}}$ letany $\mathrm{w}^{\mathrm{t}}$ faburdyn $:^{7}$

above, except that in each case he states that the execution was for denial of the king's supremacy.

I Summary inserts a note on the Earl of Kildare and his son.

2 Summary.

3 Originally this was 'xxviij.' See Introduclion p. iii.

- Summary: 'citic goynge formoste'.

5 Summary: 'schole of the mercers chapell with theyr mastar.'

6 Summary: 'mynstrels, with his collar.'

7 Summary gives simply a list of the Friars, and ends: 'all in copes, with theyr crosses and candelsticks.' 
next cam $\mathrm{y}^{\mathrm{e}}$ chanons of sent Marie Overyes, ${ }^{1} \mathrm{y}^{\mathrm{e}}$ chanons of sent Barthelmewis, $w^{\mathrm{t}} \mathrm{y}^{\mathrm{e}}$ chanons of Esynge ${ }^{2}$ spityll, \& $\mathrm{y}^{\mathrm{e}}$ chanons of sent Mary spitill, $w^{\mathrm{t}} \mathrm{y}^{\mathrm{e}}$ priours of $\mathrm{y}^{\mathrm{e}}$ same howsys $\mathrm{w}^{\mathrm{t}}$ theyr crosses $\&$ candelstykes and theyr vergirers before them, \& every chanon $\&$ priour in a cope : next aftar them came $y^{\mathrm{e}}$ clarkes of London, $\&$ every one of them a cope : aftar them $y^{\mathrm{e}}$ prystis of London, \& everie one in a cope : aftar them cam $y^{\mathrm{e}}$ monkes of Newe abbeye, $\& y^{\mathrm{e}}$ monkes of Barmondsey, $w^{\mathrm{t}} \mathrm{y}^{\mathrm{e}}$ monkes of Westmystar, syngynge, $w^{t}$ theyr crossys $\&$ vergerers $\&$ sensars, $w^{t}$ candylstyks, \& every monke a cope, $\mathrm{y}^{\mathrm{e}}$ Abotis of thes placis in copes, myteryd. ${ }^{3}$ Aftar them cam Powles quere, every priste $\&$ clerke had a cope $\mathrm{w}^{\mathrm{t}}$ all theyr residentaris in copes, syngynge the letany $\mathrm{w}^{\mathrm{t}}$ faburden ; aftar them cam $y^{\mathrm{e}}$ Abotes $\&$ priors, $\mathrm{y}^{\mathrm{t}}$ was myteryd men, in theyr pontefycallibus : than cam ij. mynstrells before $\mathrm{y}^{\mathrm{e}}$ byshope of London, who come vndar a canypie $w^{t}$ a cope on his bake, berynge betwen his hands a crosse $\mathrm{w}^{\mathrm{t}} \mathrm{y}^{\mathrm{e}}$ ost therin, \& othar relykes, \& abowghte hym was borne by $\mathrm{y}^{\mathrm{e}}$ byshopis servantis xij. torch prikes of wax brenynge lyght: ${ }^{4}$ aftar them come $y^{\mathrm{e}}$ bachilars of $y^{\mathrm{e}}$ company of my lorcle mayr in theyr aparell ${ }^{5} \mathrm{w}^{\mathrm{t}}$ theyr hoods as they dyd whan $y^{e}$ mayr toke his othe. Aftar them come my lorde mayre in a gowne of blake velvyt $w^{t}$ a hode of velvyt of $y^{\mathrm{e}}$ same. Aftar hym com xix. ${ }^{6}$ aldarmen in theyr gownes of skarlet : \& aftar them $y^{\mathrm{e}}$ craftis of London in theyr clegres. Ye nombar of copys that ware worne in this prossessyon was vij. hundred $\&$ xviij. ${ }^{7}$

The last day of Decembar my lord mayre gave comaundement

1 Summary, 'Auderies'.

${ }^{2}$ Elsing.

${ }^{3}$ Summary: 'all syngynge the Letany wyth Faburden, theyr crosses, candelstyckes, and Vergerers beefore them'.

4 Summary: "Powles quyer, with theyr Resydensaries: The byshop of London, and the Abbottes mytered in theyr Pontificalibus. ".

s Summary, "best apparell '; and omits " $w^{t}$ theyr... othe ".

6 Summary, "and the ".

7 Summary adds: "This procession was for the recoueryng of the french kyng to hys helth". See also Wriothesley Cliron. i. 32, a short account with date $12^{\text {th }}$ Nov. Stow has only a bare note in the Summary for 1575, p. $436, \&$ in the Annales. 
to all paryshes in London to brynge in before hym $\mathrm{y}^{\mathrm{e}}$ names of all $\mathrm{y}^{\mathrm{e}}$ chantries $\mathrm{w}^{\mathrm{t}}$ theyr paryshis, \& who was $\mathrm{y}^{\mathrm{e}}$ gyvars of them. ${ }^{1}$

$\mathrm{Y}^{\mathrm{e}} \mathrm{xxix}$. day of June, on sent Petar day, $\mathrm{y}^{\mathrm{e}}$ kynge made a justynge at Westmynstar ; \& ther wer ordaynyd ij. lytars, made lyke ij. shipps, to fight on $\mathrm{y}^{\mathrm{e}}$ watar, $\& \mathrm{y}^{\mathrm{e}}$ one of them braste in $\mathrm{y}^{\mathrm{e}}$ mydes, \& a sarvant ${ }^{2}$ of mstar. Knevytis in his harnys lepynge betwen bothe shypes was drownyd : \& in $y^{\mathrm{e}}$ othar shippe a gonne brast hir chambar $\&$ maymyd ij. of $y^{\mathrm{e}}$ marynars. ${ }^{3}$

Sir Rauffe Warryn, mayre. The xij. day of Norembar sir Thomas Newman bare a fagot at Powles crosse, for $\mathrm{y}^{\mathrm{t}}$ he song mas $\mathrm{w}^{\mathrm{t}}$ good alle. The xiij. day of Novembar Mst. Packenton was slayne $w^{t} a$ gone in Chepe as he went to S. Thomas of Acres to here masse. The xix.day of Novembar Myryll, a tylar, dwellynge in sent Pulkers ${ }^{5}$ paryshe, bare a fagot at Poles crosse for heresye. The $\mathrm{x}$. day of Decembar $y^{\mathrm{e}}$ parson of Sansted bysyd Hoddon ${ }^{6}$ bare a fagot at Poles crosse for heresye. ${ }^{7}$

The xxix. day of Marche, beynge maundy Thursdaye, wer xij. men of Lyncolne drawne from Newgate to Tyborne, \& ther hangyd \& quarteryd: v. wer prystis, \& vij. wer laye men, one was doctor Makeryll $^{8}$, a whit canon, another was $\mathrm{y}^{\mathrm{e}}$ vycar of Lowthe ${ }^{9}$ in Lyncolnshire.

1 Summary, "who hadde the gyfte of the same". Stow then adds nearly two pages from Hall's Chronicle.

2 Called 'one Gates gentleman' in Annales, 965.

3 Summary then inserts an account of the insurrection in Yorkshire.

- In the Summary Stow gives the account of Packenton's murder in his own words, adding "the murderer was never openly knowen". In the Summary for 1575, p. 439 , as in the Survey, i. 26I, he says : "the murderer was neuer discouered, but by his owne confession made when he came to the gallowes at Banbury, to be hanged for fellony." See Hall, Chronicle; Holinshed, iii. 883; and Gairdner, Lollardy and the Reformation, ii. 382 .

5 St Sepulchre's.

${ }^{6}$ Stanstead near Hoddesdon, Herts.

7 Summary omits the last two notes, but adds notices of the rising in Yorkshire, and other matters.

8 Matthew Makkarell, prior of Barlings, Lincolnshire. D.N.B. xxxv. 39I.

9 Thomas Kendall. They were executed for their share in the Lincoln rebellion. See Letters and Papers, xii. I. 70, 734 (3), 760. 
$\mathrm{Ye}^{\mathrm{e}} \mathrm{xxviij}$. yere of his reygne, $\mathrm{y}^{\mathrm{e}} \mathrm{xv}$. day of Maye, my lord Darcie $\&$ my lorde Hussaye wer had from $y^{\mathrm{e}}$ Towr of London vnto Westmystar, \& thar condemnyd. ${ }^{1}$ The xviij. day of Septembar was a grete fyar at sent Antholyns, \& myche hurt done. ${ }^{2}$

Richard Greshame, mayre, $y^{\mathrm{e}} \mathrm{xxix}$. yere of $\mathrm{y}^{\mathrm{e}}$ kings reygne. ${ }^{3}$ The xviij. day of Januarie a saltar of London was set on $\mathrm{y}^{\mathrm{e}}$ pilorie in Chepe for pakynge \& sellynge of rotton herrynge, \& vsynge of fals waytes. The $\mathrm{xxv}$. day of Januarie one stond on $\mathrm{y}^{\mathrm{e}}$ pelory in Chepe, $\&$ his eres cut of $\&$ nayllyd to $y^{\mathrm{e}}$ pyllorye for raylynge on $\mathrm{y}^{\mathrm{e}}$ kyngs councell. ${ }^{4}$ The xviij.day of Februarie a sarvant of my lady Pargiters ${ }^{5}$ was drawne, hangyd, \& quarteryd for clypping of golde. The xxv. day of February sir Allyn, a pryst, \& a gentyllman ${ }^{6}$ were bothe drawne to Tyborne, \& ther hangyd, \& quarteryd for treson. The xxj. day of Marche Hary Harssam, customar of Plomouthe, ${ }^{7}$ was drawne from Newgate to 'Tyborne, \& ther hangyd, \& quarteryd for treson : \& one Thomas Ewell ${ }^{8}$ lykewyse hangyd \& quarteryd. ${ }^{9}$ $\mathrm{Y}^{\mathrm{e}} \mathrm{xxvij}$. of May was $\mathrm{y}^{\mathrm{e}}$ fyar in Rode lane. Ye first day of Septembar $\mathrm{y}^{\mathrm{e}}$ hangman was hongyd at $\mathrm{y}^{\mathrm{e}}$ wrestlyng place. ${ }^{\mathrm{i}}$

Wylyam Ferman. ${ }^{11}$ mayre, $\mathrm{y}^{\mathrm{e}} 30$ yer of $\mathrm{y}^{\mathrm{e}}$ kynges reygne. ${ }^{12} \mathrm{Y}^{\mathrm{e}}$ $\mathrm{xvj}$. day of Novembar was $\mathrm{y}^{\mathrm{e}}$ blake fryars in London put downe, \&

1 Summary adds a notice of their execution.

"Summary omits, but adds notes on Cromwell's creation as K. G., and on the birth of Edward vi.

${ }^{3}$ Summary' inserts notices of the burial of Queen Jane, and of the Christmas court.

4 Summary omits.

5 Wife of Sir Thomas Pargitor, mayor, 1530-31. See Wriothesley. Chron. i. 73.

6 'Sir John Allen... and an Irish Gentleman of the Garrets'. Annales, 969.

i Thomas Harford of Plymouth. Letlers and Papers, xiii. I. $5^{\mathrm{So}}$, with date $22^{\text {nd }}$ March. So also Wriothesley, Chron., i. 77.

8 IVriothesley calls him Yewer; and Greyfriars Chron. p. 20I, Hever.

9 Summary adds a note on Friar Forest.

10 Summary gives these two notes at more length, and between them inserts a note of the treason of Edmond Conyngsbie. The year closes with notes on the removal of images, and suppression of abbeys from Hall.

11 Or Forman.

12 Summary inserts a long note on Nicholas Gibson's charities. 
$\mathrm{y}^{\mathrm{e}}$ next day $\mathrm{y}^{\mathrm{e}}$ whiht fryers put downe. $\mathrm{Y}^{\mathrm{e}}$ neste day $\mathrm{y}^{\mathrm{e}}$ gray fryars, $\& \mathrm{y}^{\mathrm{e}}$ monkes of $\mathrm{y}^{\mathrm{e}}$ Chartarhosse put downe. ${ }^{1}$ The xxij. day of Novembar was Lambart ${ }^{2}$ byrnt in Smythe fylde. The xxiiij. day of Novembar was iij. buchars, \& a woman bare fagolts at Poles. The viij. day of Decembar a priste of sent Margaretis in Frydaye strete bare a fagot at Poles for heresye. ${ }^{3}$ The xxij. clay of Decembar a pryste, \& a bryke layar called Harie Daunce, ${ }^{4} \&$ an organe makar bare fagotis at Poles crosse. ${ }^{5}$ The iij. day of Marche syr Nycholas Carrow, knyght \& mastar of $\mathrm{y}^{\mathrm{e}}$ horsse, was hedyd at $\mathrm{y}^{\mathrm{e}}$ Towr hyll. ${ }^{6}$ The viij. day of Maye was $y^{e}$ great mustar in Lonclon. ${ }^{7}$ $\mathrm{Y}^{\mathrm{e}}$ viij. day of Julii $\mathrm{y}^{\mathrm{e}}$ vycar of Wandworthe, ${ }^{8}$ his chapleyne, \& his servante, \& fryar Wayre wer all four clrawne frome $y^{e}$ Marshalcy vnto sent Thomas Wateryng, \& ther hangyd \& quarteryd for treson. ${ }^{9}$

$\mathrm{Y}^{\mathrm{e}} \mathrm{xxxj}$. yere of $\mathrm{y}^{\mathrm{e}}$ kynge, Mastar Holyes, mayre. The x. clay of June $y^{e}$ lorde Cromewell was sent to $y^{e}$ Towre of London. This Cromwell his fathar was an Irysheman borne, \& a smythe by his occupacion, \& aftar that he kepte a brewe howse at Wandworthe, $\&$ ther was this Cromwell borne, $\&$ at $\mathrm{y}^{\mathrm{e}}$ last comynge in favour $\mathrm{w}^{\mathrm{t}}$ $\mathrm{y}^{\mathrm{e}}$ kynge Henry ye eyght, he made hym linyght, \& lorde privy seale,

1 Summary adds: ' and so al the other immediatly after.'

'Summary: 'John Nicholson otherwyse Lambert, a priest,' from Hall. Wriothesley Chron. i. 88 calls him William Nicholson.

3 Summary omits these two notes, but inserts one on the arrest of the Marquis of Exeter and Sir Henry Pole.

4 His real name was John Harridaunce: he used to preach in his garden at Whitechapel. See Gairdner, Lollardy and the Reformalion, i. 208, Wriothesley, Chron. i. 82, 93, and Letters and Papers, xiv. ii. 42 (I, 2).

5 Summary inserts a note on the execution of John Johns and others for murder of Roger Cholmeley.

6 Summary is somewhat fuller, and then inserts notes on the promotion of Paulet \& Russell, the fortification of havens, \& attainders in Parliament.

7 Summary has a full notice similar to that in Survey, i. I03.

\& Griffith Clarke, Annales, 972. Wriothesley, Chron. i. Io I calls him 'chaplaine to the Marques of Exceter.'

9 Summary adds notes on O'Neill's rebellion in Ireland, and the negotiation of Henry's marriage to Anne of Cleves. 
$\&$ then vycegerent, \& aftar lord chamberleyne, \& then yearle of Essyxe, \& thus he browght hym vp of noghte. The xxviij. day of Julii was the lord Cromewell, ${ }^{1} \& \mathrm{y}^{\mathrm{e}}$ lorde Hongarforde behedyd at $\mathrm{y}^{\mathrm{e}}$ Towr hyll for treson.

The iiij. day of August wer drawne from $y^{e}$ Towre to Tyborne vj. persons, \& one led betwen ij. sargantis, \& ther hangyd \& quarteryd : one of them was $\mathrm{y}^{\mathrm{e}}$ prior of Dancastor, a monke of $\mathrm{y}^{\mathrm{e}}$ Chartarhouse of London, Gyles Herne a monke of Westmystar, one Fylpot, \& one Carrow, \& a fryar : all were put to death for treason. ${ }^{2}$ This yere $y^{\mathrm{e}}$ dychys abowt London wer new cast.

Syr Wylyam Roche, mayre, in $y^{\mathrm{e}} 32$ yere $y^{\mathrm{e}}$ kyngs reygne.

The xxxiij. yere of his reygue.

Michaell Dormer, mayre, in $y^{\mathrm{e}} 33$ of Henrie $y^{\mathrm{e}}$ viij.

The xxxiiij. yere of $y^{\mathrm{e}}$ kyngs reygne.

John Cotes, mayre. The xxiij. day of Novembar wer ij. men hangyd in Holborne fylde for kyllynge a woman ${ }^{3}$.

The xxxv. yere of his reygne.

Sir Wyllyam Boyere, mayre, in $y^{\mathrm{e}} 35$ yere of Henrie $\mathrm{y}^{\mathrm{e}}$ viij.

The xxxvj. yere of his reygne.

Syr Wylyam Laxton, mayre, in $y^{\mathrm{e}} 36$ yere of Henrie $y^{\mathrm{e}}$ viij.

The xxij. of Aprill ye xxxvij. of his reygne.

1 The whole of this curious note is omitted in the Summary. Though clearly a contemporary story it is in point of fact inaccurate. Thomas Cromwell's father, Walter Cromwell or Smythe, was it is true a blacksmith and brewhouse keeper at Putney: but the family had been settled there since 1452, and came from Norwell in Nottinghamshire. See D.N.B. xiii. 192. The Summary has a long and independent account for this year, borrowing only the next paragraph from the Chroniclc.

2 See Annales, 977; Laurence Cooke, prior of Doncaster, William Horne, laybrother of the Charterhouse, Giles Horne, gentleman, Clement Philip, gentleman, Edward Bromholme, priest, Darby Gening and Robert Bird executed for denying the king's supremacy. Wriothesley, Chron. i. I2 I has 'Clement Philpott,' and says Charles Carow, gentleman was 'hanged for robbing of my Ladie Carow'.

3 Summary omits. Wriothesley Chron. i. I37: 'In November were hanged on the backsyde of Lincolnes Inne two persons for murtheringe one Thomas Chesshers mayde in the same place'. 
Sir Martin Bowes, mayre, y 37 of Henry $y^{\mathrm{e}} 8$.

The xxij. of Aprill $y^{\mathfrak{e}}$ xxxviij. yere of his reygne.

Henri Hubarthorn, mayre, $y^{\mathrm{e}} \mathrm{xxviij}$. of Novembar ${ }^{1}$ in $\mathrm{y}^{\mathrm{e}} 38$ of Henrie 8.

The first yere of $y^{e}$ kynge Edward $y^{e}$ vj. $y^{e}$ xxviij. of January.

Sir John Gressham, mercar, mayre in $y^{\mathrm{e}} 1$. yere of Edward $\mathrm{y}^{\mathrm{e}} 6$.

The second yere of $y^{e}$ kynge $y^{e} \mathrm{xxviij}$. of Januarie.

Mst. Hamcotis, ${ }^{2}$ fishemongar, mayr, y 2 yere of Ed. 6.

The xx. day of Marche sir Thomas Seymar, knyght, lord admyrall, was behedyd at Towre hyll. This yere $\mathrm{y}^{\mathrm{e}}$ comons in all $\mathrm{y}^{\mathrm{e}}$ parties of England made sondry insurreccions \& commocions about whitsontyde, \& so forthe vntyll September : amongs whome dyvers of comons of Cornwall \& Devonshire ${ }^{3}$ in sondry campes besegyd Excester, whiche manfully was defendyd ${ }^{4}$ by $\mathrm{y}^{\mathrm{e}}$ inhabytauntes $\&$ dyver gentylmen which were flede into it. And agaynst thes rebells were sent $y^{\mathrm{e}}$ lorde Russell, lorde privy seale, who lay longe ther at Hontyngton, ${ }^{5}$ vntyll $y^{\mathrm{e}}$ lord Graye $\mathrm{w}^{\mathrm{t}}$ certayne strayngars horsmen in redd cottes came thether, \& syr Wyllyam Herbart $w^{t}$ dyvers Welchemen, \& at a towne callyd Byshopps Clyffte ${ }^{6}$ they assaltyd one campe furnyshed $\mathrm{w}^{\mathrm{t}}$ a greate number of $\mathrm{y}^{\mathrm{e}}$ sayd rebelles \& them vanquished. And $y^{\mathrm{e}}$ othar Rebells lying before Exceter, herynge of $\mathrm{y}^{\mathrm{e}}$ ovarthrow of theyr companyons at Bysshoppis Clyfte, beynge in feare of $\mathrm{y}^{\mathrm{e}}$ kynges Army, fled frome $\mathrm{y}^{\mathrm{e}}$ sege beyonde Excester into Cornwall, ${ }^{7}$ so that the lordes aforesayd entred into Exceter $w^{t}$ out any further troble, yet $y^{\text {ey }}$ left not $y^{\mathrm{e}}$ sayd rebells but chasd them into Cornewall, \& take one Humfrey Arundell, one of $y^{\mathrm{e}}$ capitaynes,

${ }^{1}$ Sic. Perhaps an error for $28^{\text {th }}$ Sept.; Wriothesley (i. 175) says Hubberthorne was the first mayor chosen on that date.

2 Sir Henry Amcotes.

${ }^{3}$ Summary inserts: " rose agaynst the nobles and gentelmen: and."

4 Summary, 'whyche was valyauntly defender.' Stow then continues more briefly in his own words.

5 Honiton.

6 Bishop Clist.

7 Another handwriting begins. 
$\&$ one

${ }^{1}$ Pomery, $\mathrm{w}^{\mathrm{t}}$ dyuerse other, $\&$ slewe very many : the contry was very sore wasted not only by reason of thar long lyenge ther in sondry campes, but also for that all the company of $\mathrm{y}^{\mathrm{e}}$ lordes $\mathrm{y}^{\mathrm{e}}$ strange had leave to spoyle.

'Also durynge this seege $y^{\mathrm{e}}$ comons of Oxfordshire, Northamptonshire, \& Bedfordshire, $w^{t}$ dyvars of Somersettshire $\&$ others, arose in great numbers, \& $\mathbf{w}^{\mathrm{t}}$ great angre towards sir John Wyllyams disparkyd his parke called Thame parke, \& kyllyd all $y^{\mathrm{e}}$ dere : from thens they went vnto Rycote, $\&$ ther dysparked $y^{\mathrm{e}}$ parke called Rycote parke, \& kyllyd all his dere, entered into $y^{\mathrm{e}}$ place, \& dranke theyr fyll of wyne, ale $\&$ bere, slew many shepe, $\&$ ete them, $w^{t}$ dyvers other myscheves: from thens they went vnto Woodstocke, $\&$ then herynge $\mathrm{y}^{\mathrm{t}}$ my lorde Gray $\mathrm{w}^{\mathrm{t}} \mathrm{y}^{\mathrm{e}}$ kyngs powre was comynge towards them, many of thern forsoke theyr companye, \& thos whiche remaynyd went vnto a towne callyd Chyppynge Norton, where they encampyd themselves, whithar my lorde Graye folowyd them, \& ther ovarcame them, \& toke one Thomas Bowldrey, who aftar was hangyd \& quarteryd, \& one Bowlar, whiche aftarwards had his pardon : those $\mathrm{ij}$. were capitayns at the brakynge vp $\mathrm{y}^{\mathbf{e}}$ parks. ${ }^{3}$

And also duryng $\mathrm{y}^{\mathrm{e}}$ sege at Exetar $\mathrm{y}^{\mathrm{e}}$ comons of Norfolke \& Suffolke arose in great nombar, \& came vnto Norwytche, \& nere there vnto in a wode callyd S. Nicholas wood they encampyd themselves, \& aganst them was sent $\mathrm{y}^{\mathrm{e}}$ Erle of Essex, whyche was made markes Northampton, $w^{t}$ dyvers straungers $\&$ englyshe inen, all horssemen, " whome these rebelles suffred to enter into Norwiche peceably; but after $\mathrm{y}^{\mathrm{t}}$ he had entered $\mathrm{y}^{\mathrm{e}}$ towne they neuer left of from molestynge \& assaultynge $y^{e}$ towne, so $y^{t}$ in $y^{\mathrm{e}}$ conclusion he was fayne to forsake $\mathrm{y}^{\mathrm{e}}$ towne \& leave behynde many of his companye $\mathrm{w}^{\mathrm{t}}$ moch mony, stuff, horses, \& other caryage : after $\mathrm{y}^{\mathrm{t}}$ those rebelles $\mathrm{w}^{\mathrm{t}}$ ther capyteyn, called Keet ${ }^{\mathrm{s}} \mathrm{y}^{\mathrm{e}}$ tanner,

${ }^{1}$ Blank in MS. He was Sir Thomas Pomeroy.

2 Stow resumes writing.

${ }^{3}$ Stow makes no use of this. In future I shall note only his quotations.

4 The other hand resumes.

${ }^{3}$ Robert Kett. 
burned dyuerse houses $w^{t}$ in $y^{e}$ citie of Norwiche, $\&$ spoyled many honest marchauntes of ther goodes to ther ympoueryshinge. Also he tooke all $\mathrm{y}^{\mathrm{e}}$ gentilmen $\mathrm{y}^{\mathrm{t}}$ he myghte gett, \& cheyned them together entreatynge them very cruelly : wherfore for $\mathrm{y}^{\mathrm{e}}$ appeasinge of this vprore therle of Warwyke was sent thyther $w^{t} y^{e}$ kynges power, who did so handell the matter $y^{t}$ aboute the begynnynge of September, ${ }^{1}$ bartellmewtyd, he ouer came them, \& toke ther capitayn, called Keet $y^{\mathrm{e}}$ tanner,whome he sent to London to $\mathrm{y}^{\mathrm{e}}$ kynge, by whos commaundement $\mathrm{y}^{\mathrm{e}}$ same Keet was broughte throughe London $y^{\mathrm{e}}$ last of September, \& $w^{\mathrm{t}}$ hym a brother of hys also, wh. were both broughte into $\mathrm{y}^{\mathrm{e}}$ Tower.

ffor $y^{e}$ which offence $y^{e}$ sayd Keet $y^{e}$ tanner was hanged vppon $\mathrm{y}^{\mathrm{e}}$ toppe of $\mathrm{y}^{\mathrm{e}}$ castell of Norwytche, and his brother also. ${ }^{2}$

xxix $^{0}$ September, $a^{0}$ iij. Regis E. vj $^{\mathrm{ti}}$.

Sir Rowland Hyll, mercer, mayour, y 3 yere of Edward 6.

This yere $y^{\mathrm{e}}$ iiijth of October $\mathrm{y}^{\mathrm{e}}$ lord protector $\&$ ye erle of Warwyke fill at controversye aboute $y^{\mathrm{e}}$ reasonynge of certeyn things, \& so $\mathrm{y}^{\mathrm{e}}$ erle of Warwyke $\mathrm{w}^{\mathrm{t}}$ other lordes of $\mathrm{y}^{\mathrm{e}}$ counsell assembled, \& $\mathrm{y}^{\mathrm{t}}$ herynge the lord protector $\mathrm{w}^{\mathrm{t}}$ all spede departed from Hampton courte, \& tooke $\mathrm{y}^{\mathrm{e}}$ kynge $\mathrm{w}^{\mathrm{t}}$ hym to $\mathrm{y}^{\mathrm{e}}$ castell of Wyndsore vppon $\mathrm{y}^{\mathrm{e}}$ sixte day of October at nyghte late, \& gathered thyther moche people, \& $w^{\mathrm{t}}$ hym went $\mathrm{y}^{\mathrm{e}}$ archbishope of Caunterberye, sir Thomas Patchett, ${ }^{3} \&$ secretary Smythe : ${ }^{4}$ wherfore $\mathrm{y}^{\mathrm{e}}$ lordes cam together vpp to London, as the lord chauncellor, ${ }^{5} \mathrm{y}^{\mathrm{e}}$ lord $\mathrm{S}^{\mathrm{t}}$ John, lord grete master, $\mathrm{w}^{\mathrm{t}}$ dyuerse other of $\mathrm{y}^{\mathrm{e}}$ kynges counsayll, \& satt at $\mathrm{y}^{\mathrm{e}}$ mercers hall in Chepesyde $\mathrm{y}^{\mathrm{e}} \mathrm{vij}^{\text {th }}$ daye of October : $\& y^{\mathrm{e}}$ viij ${ }^{\text {th }}$ day of October $\mathrm{y}^{\mathrm{e}}$ said lord protector $\mathbf{w}^{\mathrm{t}}$ all hys complices was proclaymed a traytor in London for dyuerse causes then declared in $\mathrm{y}^{\mathrm{e}}$ proclamacion : \& $\mathrm{y}^{\mathrm{e}}$ tenthe

1 On $26^{\text {th }}$ August.

2 The copyist first wrote: 'but his brother had his pardon.' His brother William was hanged at Wymondham. Two other brothers were pardoned.

3 Probably Sîr William Paget.

- Sir Thomas Smith.

3 Richard, lord Rich. 
daye $\mathrm{y}^{\mathrm{e}}$ lord protector was comytted to ward in $\mathrm{y}^{\mathrm{e}}$ castell of Wyndsor, \& after $\mathrm{y}^{\mathrm{t}}$ vppon Mondaye, beinge $\mathrm{y}^{\mathrm{e}} \mathrm{xiiij}^{\text {th }}$ of October, $\mathrm{y}^{\mathrm{e}}$ same lord protector was brought from Wyndsore vnto $\mathrm{y}^{\mathrm{e}}$ Tower throughe $\mathrm{y}^{\mathrm{e}}$ citye, \& $\mathrm{w}^{\mathrm{t}}$ hym $\mathrm{y}^{\mathrm{e}}$ same tyme was broughte M. Stanhope, ${ }^{1}$ grome of $\mathrm{y}^{\mathrm{e}}$ stole, $\&$ secretarye Smythe $\mathrm{w}^{\mathrm{t}}$ other $: \&$ after $\mathrm{y}^{\mathrm{t}}$, vppon Thursdaye, beinge saynte Lukes eve, viz. $y^{\text {,e }}$ xvij. day of October, $\mathrm{y}^{\mathrm{e}}$ kynges $\mathrm{M}^{\text {tie }}$ Edward $\mathrm{y}^{\mathrm{e}}$ sixte, accompanyed $\mathrm{w}^{\mathrm{t}}$ all $\mathrm{y}^{\mathrm{e}}$ nobilite came from Hampton corte vnto Suffolke place in Sothewerke, wher he dyned, \& after dyner rode throughe $\mathrm{y}^{\mathrm{e}}$ citie vnto Westmester in moste goodly order.

Also be it remembred ${ }^{2} y^{t}$ vppon Sondaye, beynge $y^{\mathrm{e}} \mathrm{xix}^{\text {th }}$ day of January, $A^{o} R$. E. vj. ${ }^{\text {ti }}$ tertio, in $y^{\mathrm{e}}$ evenynge after super betwene Newgate \& Smythe filde one called commonly captayn Gambold, ${ }^{3}$ $\&$ an other captayne $w^{t}$ hym called

${ }^{4}$ were both slayne by one called captayne Charles, ${ }^{5}$ whoo of very malyce $\&$ dispyte slewe $\mathrm{y}^{\mathrm{e}}$ same Gambold, $\&$ for $\mathrm{y}^{\mathrm{e}}$ same offence $\mathrm{y}^{\mathrm{e}}$ sayd captayne Charles had hys hand stryken off vpon $y^{\mathrm{e}}$ carte whelle, wher in he $w^{\text {t }}$ iij. others ${ }^{6} w^{\text {t }}$ hym were caryed from Newgate, $\&$ vpon $y^{\mathrm{e}}$ waye before $\mathrm{y}^{\mathrm{e}}$ kynges hedd taverne ${ }^{\mathrm{T}}$ lost hys hand, $\&$ so were they all iiij. hanged in Smythfeld $y^{e}$ Frydaye, next folowynge, which was $y^{e}$ $x x v .^{\text {th }}{ }^{8}$ of Januarye.

Also $\mathrm{y}^{\mathrm{e}} \mathrm{xxvj} .{ }^{\text {th }}$ day of January, $\mathrm{a} .{ }^{\circ} \mathrm{iij}^{\circ}{ }^{\circ} \mathrm{E} . \mathrm{vj}^{\mathrm{ti}}{ }^{\mathrm{t}}$, foure westerne men, viz. one called Humfrey Arundell, a gentellman borne, one Berrys, ${ }^{9}$

1 Michael Stanhope.

2 Stow Summary, and Annales, 1017, describes this rather more fully. See also Wriothesley, Chron. ii. 3 I, 32.

3 'Sir Peter Gambo, ' Stow and Wriothesley; 'Gambolde ' in Greyfriars Chron.

4 'Filicirga', Stow.

5 'Charles Gauaro', Stow; Degavaro, Wriothesley.

${ }^{6}$ Kynges head dore before Smithfield, where the Murther was committed. Summary.

7 Balthasar Gauaro, Nicholas Disalueton, and Francis Deualesco, Annales; Michael Desaluaron, and Frauncis Desalvasto, Wriothesley.

$\delta$ So Summary; $24^{\text {th }}$, Annales, and Wriothesley.

9 Bery, Stow. 
one Wynslowe, \& one called

Holmes ${ }^{1}$ were drawn, hanged, $\&$ quartered at $\mathrm{Tyborne}$ from $\mathrm{y}^{\mathrm{e}}$ Tower of London for $\mathrm{y}^{\mathrm{e}}$ insurreccion made in $\mathrm{y}^{\mathrm{e}}$ west partes, as appeareth in $\mathrm{y}^{\mathrm{e}}$ yere before.

Also $y^{\mathrm{e}}$ vj. $^{\text {th }}$ of ffebruary, a. ${ }^{\circ}$ R. E. vj. $^{\text {ti }}$, iiij $^{\text {to }}$, the duke of Somerset, wh. as aforesayd beynge lord protector proclaymed traytor $\&$ commytted vnto $\mathrm{y}^{\mathrm{e}}$ Tower, was nowe delyuered out of $\mathrm{y}^{\mathrm{e}}$ Tower, \& $\mathrm{y}^{\mathrm{e}}$ same nyghte supped $\mathrm{w}^{\mathrm{t}} \mathrm{y}^{\mathrm{e}}$ erle of Warwyke at $\mathrm{y}^{\mathrm{e}}$ shreffes called mr. Yorke. ${ }^{2}$

Also vppon Mondaye, beinge $y^{e}$ tenth daye of ffebruary afforesayde, one Bell, a Suffolkeman was drawen from ye Tower vnto $\mathrm{y}^{\mathrm{e}}$ Tyburne, \& ther hanged $\&$ quartred, which as they sayd was for a newe insurreccion, wh. he $\mathrm{w}^{\mathrm{t}}$ certayne other of his complyces moved in Suffolke $\&$ in Essexe. ${ }^{2}$

Also vpon Mondaye, beinge $y^{\mathrm{e}}$ last daye of Marche, a. ${ }^{\circ} \mathrm{R} . \mathrm{E} . \mathrm{vj}^{\mathrm{ti}}$ iiij $^{\text {to }}$, a generall peace was proclaymed throughe London betwene $\mathrm{y}^{\mathrm{e}}$ kynge our M., \& $\mathrm{y}^{\mathrm{e}}$ ffrench kynge, \& in $\mathrm{y}^{\mathrm{e}}$ same peace were included themperor $\& y^{\mathrm{e}}$ scotes $:^{3} \mathrm{y}^{\mathrm{e}}$ condicions of $\mathrm{y}^{\mathrm{e}}$ wh. peace as some sayd were thes $\mathrm{y}^{\mathrm{t}}$ followe. ${ }^{4}$

Be it remembred $y^{t} y^{e} x_{x v j .}{ }^{\text {th }}$ of Aprill, anno R. E. vj..$^{\text {ti }}$ quarto, $y^{e}$ towne of Bulloyne was yelden vp vnto $y^{\mathrm{e}}$ french kynge, $\&$ hys capitaynes tooke $\mathrm{y}^{\mathrm{e}}$ possession, which was so greate comforte $\&$ joye to $y^{e}$ ffrench men, $y^{t}$ as some sayd at ye entrye in to $y^{e}$ towne many of them kneled downe $\&$ kyssed $\mathrm{y}^{\mathrm{e}}$ stones of $\mathrm{y}^{\mathrm{e}}$ stretes. $^{j}$

$\mathrm{Be}$ it also remembred $\mathrm{y}^{\mathrm{t}}$ vppon ffryday, beynge $\mathrm{y}^{\mathrm{e}}$ seconde daye of Maye, one Joan of Kent, otherwyse called Joan Bocher, was borned in Smythfild for heresy, whose pryncrypall article was our saviour Chryst tooke nether flesh nor blood of $\mathrm{y}^{\mathrm{e}}$ vyrgyn Mary. ${ }^{6}$

The xxix of October $\mathrm{a}^{\circ}$ iiij $^{\text {to }} \mathrm{E} . \mathrm{vj}^{\mathrm{ti}}{ }^{\mathrm{i}}$

M. Andrew Jude, skynner, mayor, 1550, a. $^{\circ} 4$. E. vj.ti

1 Thomas Holmes, Stow.

2 Quoted with slight variation in Summary.

3 Summary.

4 Not given in MS., nor by Stow.

5 Summary.

6 Summary with some variations. 
This yere vppon a Thursdaye, beynge $y^{\mathbf{e}} \mathrm{xvij}^{\text {th }}$ of Decembar, $\mathrm{y}^{\mathbf{e}}$ Temes beneth $\mathrm{y}^{\mathrm{e}}$ brydge dyd ebbe $\&$ flow thre tymes $\mathrm{w}^{\mathrm{t}}$ in ix. howres, $\& \mathrm{y}^{\mathrm{e}}$ very same daye $\mathrm{y}^{\mathrm{e}}$ bishope of Winchester, who had lyen in $y^{\mathrm{e}}$ Tower from $y^{\mathrm{e}}$ mowow after saynt Peters daye a. ${ }^{\circ}$ primo E. vj. ${ }^{\text {ti }}$, was broughte vnto Lambethe before $y^{e}$ bishope of Caunterbery $\&$ certeyne of $\mathrm{y}^{\mathrm{e}}$ kynges comyssyoners ther vnto appoynted, where were obiected vnto hym certeyne articles on $y^{\text {e }}$ kynges behalfe, \& daye assigned vnto his answere, ${ }^{3}$ at wh. daye he exhibyted a matter Justificatory $\mathrm{w}^{\mathrm{t}}$ certayne Interrogatoryes, vppon $\mathrm{y}^{\mathrm{e}}$ wh. articles, mattier justifycatory, \& interrogatoryes were very many nobell men $\&$ other witnesses examined, \& dyuerse dayes $\mathrm{y}^{\mathrm{e}}$ sayd L. of Wynchester hadd accordynge to $\mathrm{y}^{\mathrm{e}}$ order of $\mathrm{y}^{\mathrm{e}}$ lawe.

A. ${ }^{0}$ v $^{\text {to }}$ E. vj..$^{\text {ti }}$

Also be it remembred $y^{t}$ vppon Satterdaye $y^{\mathbf{e}}$ vj. off ffebruary $y^{\mathbf{e}}$ same L. of Winchester was before $y^{\mathrm{e}}$ sayde comyssyoners, \& was deprived from his bisshoprik.

$\mathrm{Be}$ it remembred $\mathrm{y}^{\mathrm{t}}$ vppon ffrydaye, beynge $\mathrm{y}^{\mathrm{e}} 13$ of Marche, one Thomas Morysbye \& his syster were both hanged in Smythfild for murderyng of a gentyllman dwellynge in ffeuersham, called Arden, who was murdred by his owne wyffe, \& thother ij. abouenamed : for $y^{\mathrm{e}}$ wh. murder as $\mathrm{y}^{\mathrm{e}}$ saynge was his wyffe was also barned at Canterbury aboute $y^{\mathrm{e}}$ xiij. $^{\text {th }}$ daye of Marche, \& twoo other also suffred at Feuersham $y^{\mathrm{e}}$ same daye. ${ }^{2}$

$\mathrm{Be}$ it also remembred $\mathrm{y}^{\mathrm{t}}$ this yere were clene put downe all $\mathrm{y}^{\mathrm{e}}$ alters wh. were left stondynge in London; for in dyuerse places in England, \& in sondry parishes of London $y^{\mathrm{e}}$ had been pulled downe longe affore, excepte $S^{t}$. Nicholas Willows, \& tables of waynscott set in $\mathrm{y}^{\mathrm{e}}$ myddest of $\mathrm{y}^{\mathrm{e}}$ quere ; $\&$ in $\mathrm{y}^{\mathrm{e}}$ begynnynge of $\mathrm{y}^{\mathrm{e}}$ moneth of Aprill $^{3} \mathrm{y}^{\mathrm{e}}$ yron gates of $\mathrm{y}^{\mathrm{e}}$ quere of Paules were mured vpp $\mathrm{w}^{\mathrm{t}}$ bryke bycause many people cam thyther dayly \& worshipe $y^{e}$ sacrament.

1 Thus far in Summary. Gardiner was remitted from time to time till $\mathbf{I}^{\text {th }}$ Feb. 155I.

2 Summary gives this at more length from another source.

3 "Against Easter", Wriothesley, Chron. ii. 47. 
Be it also remembred $y^{t}$ vppon ffryday, beynge $y^{e}$ xxiiij. ${ }^{\text {th }}$ of Aprell, a dutcheman was burned in Smythfilld for heresy, whose detestabell heresy was of $\mathrm{y}^{\mathrm{e}}$ inequalitie betweene God $\mathrm{y}^{\mathrm{e}}$ father, \& God ye sonne. ${ }^{1}$

Be it also remembred $y^{t}$ vppon ffryday, beinge $y^{e}$ viij. of Maye, a proclamacion was made in London $\mathrm{y}^{\mathrm{t}}$, from \& after $\mathrm{y}^{\mathrm{e}}$ last daye of August then next ensewynge, shyllynges of $y^{e}$ valewe of xij.d. shuld be currant but ix.d., \& a grote for iij. pence. By reason of wh. proclaymacion ensewed great death ${ }^{2}$ of all thynges ; for $\mathrm{y}^{\mathrm{e}}$ people, coueytinge to rayse $\mathrm{y}^{\mathrm{e}}$ losse of theyr money vppon soche kynd of wares or victualles as they occupyed, dyd dayly inhaunse $\&$ encrease $\mathrm{y}^{\mathrm{e}}$ prises both of wares $\&$ victualles, most miserably oppressynge $\mathrm{y}^{\mathrm{e}}$ poore. $^{3}$

Nota. $y^{t}$ vppon Mondaye, beynge $y^{e} x x^{\text {th }}$. of Maye, betwene $\mathrm{y}^{\mathrm{e}}$ howres of $\mathrm{xj}$. \& one of $\mathrm{y}^{\mathrm{e}}$ clocke at none was an erthequake of halfe a quarter of an hower longe at Blechyngelye, at Godstone, at Croydon, at Albery, \& dyuerse other places ther aboutes : ye cause therof is onely knowen vnto God, who be merciful vnto vs. ${ }^{4}$

Also be it remembred $\mathrm{y}^{\mathrm{t}}$ vppon Thursdaye, beinge $\mathrm{y}^{\mathrm{e}} \mathrm{ix}^{\mathrm{th}}$. of July, $\mathrm{y}^{\mathrm{e}}$ forsayd proclamacion, wh. was appoynted to take effecte $\mathrm{y}^{\ominus}$ last day of August next comynge, by reason of $\mathrm{y}^{\mathrm{e}}$ insatyabell covetous of $\mathrm{y}^{\mathrm{e}}$ people oppressynge $\mathrm{y}^{\mathrm{e}}$ pore in ouerprysing, especially of vytayll \& generally all other kyndes of warres, was shortened vnto this presente daye, \& tooke effecte ymedyatly vppon $\mathrm{y}^{\mathrm{e}}$ publyshynge of $\mathrm{y}^{\mathrm{e}}$ same, wh. was doon betwene ix. \& $\mathrm{x}$. of $\mathrm{y}^{\mathrm{e}}$ clocke beforenone of $\mathrm{y}^{\mathrm{e}}$ same ix. daye, so $\mathrm{y}^{\mathrm{t}}$ ymedyatly a shyllynge went for ix.d. \& a grote for iij.d., \& no word spoken of $y^{e}$ small money as pence $\&$ halfe grotes, by reason whereof ther was no small money to be gotten to geve $\mathrm{y}^{\mathrm{e}}$ poore people. ${ }^{5}$

1 Summary ending: 'who helde the detestable opinion of the Arrians '. His name was George of Paris, Annales, I02I.

2 Read 'dearth' as in Summary.

3 Summary with slight variations.

4 Summary ending: 'places in Southery and Myddlesexe.' See Wriothesley, Chron. ii. 49.

- Summary. 
$\mathrm{Be}$ it also remembred $y^{t}$ vppon ffrydaye, $y^{\mathrm{e}} \mathrm{x}^{\text {th }}$. of July, $\mathrm{y}^{\mathrm{e}}$ swetinge sycknes was very vehemente in London. But specially Watlyngstret, so $\mathrm{y}^{\mathrm{t}}$ in $\mathrm{y}^{\mathrm{e}}$ same daye dyed many. ${ }^{1}$

Bee it remembred $\mathrm{y}^{\mathrm{t}}$ at St. Nicholas wyllows $\mathrm{y}^{\mathrm{e}}$ altars stood yet styll, as $\mathrm{y}^{\mathrm{t}} \mathrm{y}^{\mathrm{e}}$ precher $\mathrm{M}$. Horne was very ernest agaynst them in $\mathrm{y}^{\mathrm{e}}$ afternoon $\mathrm{y}^{\mathrm{t}}$ he made.

$\mathrm{Be}$ it remembred $\mathrm{y}^{\mathrm{t}}$ vpon a Monday, beinge $\mathrm{y}^{\mathrm{e}} \mathrm{xvij}$.th . of August $a^{o}$. R. E. $v^{\text {ti }}$ Quinto, $y^{\mathrm{e}}$ proclaymacion cam forth for a shyllyng to be currant for vj.d., a grote for ij.d., a peny of ij.d. for a peny, a peny for a ob., \& a ob. for a qr. ${ }^{2}$

Be it remembred $y^{t}$ vppon Sondaye $y^{e} x^{\text {th }}$. of October $y^{e}$ lorde marques Dorset was created duke of Suffolke, $y^{e}$ lord erlle of Warwyke was created duke of Northumberland, \& $y^{\mathrm{e}}$ erle of Wyltesh. was created marques of Wynchester, \& sir Willyam Harbert y $^{\mathbf{e}}$ master of $\mathrm{y}^{\mathrm{e}}$ horse was created erle of Penbroke, \& dyuerse men made knyghtes. ${ }^{3}$

Be it further remembred $y^{t}$ vppon ffryclaye $y^{\mathrm{e}} 16$ of October $y^{\mathrm{e}}$ duke of Somerset was brought vnto $y^{\text {e }}$ Tower, $\&$ in $y^{\mathrm{e}}$ next mornynge beynge Satterdaye $\mathrm{y}^{\mathrm{e}}$ duchesse his wyfe was broughte thyther also, \& ther wente also $w^{t} y^{\mathrm{e}}$ duke the lord Grey of Wylton, sir Raffe Vane, \& sir Thomas Pallmer, ${ }^{4} \&$ sondrye other men bothe of $\mathrm{y}^{\mathrm{e}}$ dukes seruauntes $\&$ of others.

29 Octobers 1551.

M. Richard Dobbes, skynner, Mayor, $\mathrm{y}^{\mathrm{e}} 5$ yere of Ed. 6 .

$\mathrm{No}^{\mathrm{m}} \cdot{ }^{5}$ that vppon ffrydaye, beynge $\mathrm{y}^{\mathrm{e}} 30$ of October, a newe proclamacion cum forth for sondrye newe peces of money both sylver \& golde of dyuerse valewes, viz. souereignes of fyne gould at xxx.s., angelles of fyne golde at x., \& dyuerse other peces of gold

1 Summary much longer.

2 Summary with some variation.

3 Summary.

'Summary inserts: "Syr Mylles Petrydge, syr Michell Stonhope, syr Thomas Arundell. '

${ }^{5}$ sc. Notandum. 
of lesser valewes, a pece of syluer v.s, \& a pece ii., vj.d., $y^{\mathrm{e}}$ sterlynge shillinge of xij.d. \& sondry other small moneyes. ${ }^{1}$

Note also yt uppon ffrydaye, beynge $y^{\mathrm{e}} \mathrm{vj}^{\text {th }}$. daye of Nouember $\mathrm{y}^{\mathrm{e}}$ quene of scottes ${ }^{2}$ rode throughe Chepesyde $\mathrm{w}^{\mathrm{t}}$ a greate companye of englishemen waytynge on her, after she had lyen iiij. dayes in $\mathrm{y}^{\mathrm{e}}$ byshope of London's palace besydes Poules churche.

Note further $\mathrm{y}^{\mathrm{t}}$ vppon Tewesdaye $\mathrm{y}^{\mathrm{e}}$ first of December $\mathrm{y}^{\mathrm{e}}$ duke of Somerset was areyned at Westmynster hall, \& was then \& ther acquyted of treason, but he was condempned of felonye by vertue of acte of parlyamente made agaynst conventicles \& vnlawfull assemblies. $^{3}$

Also vppon $y^{\mathrm{e}}$ Mondaye after, beynge $\mathrm{y}^{\mathrm{e}} \mathrm{vij}^{\text {th }}$. daye of December was a generall muster of $\mathrm{y}^{\mathrm{e}}$ horsemen, wh. were in $\mathrm{y}^{\mathrm{e}}$ wages of $\mathrm{y}^{\mathrm{e}}$ nobles of this realme, \& for $\mathrm{y}^{\mathrm{e}}$ wh. $\mathrm{y}^{\mathrm{e}}$ kynges majesty allowed yerely for each man xx.li., the wh. muster was made vppon $\mathrm{y}^{\mathrm{e}}$ brod cawsey ouer agaynste $y^{\mathrm{e}}$ brode causaye ouer agaynst $\mathrm{y}^{\mathrm{e}}$ kinges place $^{4}$ at saynte James : \& as $\mathrm{y}^{\mathrm{t}}$ was reported $\mathrm{y}^{\mathrm{e}}$ nomber of $\mathrm{y}^{\mathrm{e}}$ horsemen was a thousande.

Note $y^{t}$ vppon ffrydaye, beynge $y^{\mathrm{e}} \mathrm{xxij}{ }^{\text {th }}$. day of January, $\mathrm{y}^{\mathrm{e}}$ duke of Somerset was broughte vnto $\mathrm{y}^{\mathrm{e}}$ skaffold vppon $\mathrm{y}^{\mathrm{e}}$ Tower hyll, \& ther was beheaded.

And vppon Satterdaye $y^{\mathrm{e}} \mathrm{xxiij}^{\text {th }}$. daye of Januarye $\mathrm{y}^{\mathrm{e}}$ parlyament began wh. $y^{\text {e }}$ lorcles assembled.

Also about this tyme $\mathrm{y}^{\mathrm{e}}$ flud of $\mathrm{y}^{\mathrm{e}}$ ocean \& flemyshe sea of $\mathrm{y}^{\mathrm{e}}$ Temes swelled so hyghe $\mathrm{y}^{\mathrm{t}} \mathrm{yt}$ dyde greate hurte vpon all $\mathrm{y}^{\mathrm{e}}$ cost of Flaunders, \& ouerflowed Lesynge ${ }^{5}$ mershe besydes Wolwytche, $\& \mathrm{y}^{\mathrm{e}}$ mershes beyond saynte Kateryns.

Also aboute this tyme ther was found clead in $y^{\mathrm{e}}$ mouth of $\mathrm{y}^{\mathrm{e}}$ Humber in $y^{e}$ north a greate whale of vij. or viij. cubites.

\footnotetext{
1 Summary.

'Summary: 'The old Quene of Scottes.'

3 Summary.

- So in MS. Summary: ' made vpon the caussey ouer against the kynges palace.'

s Lesnes. A somewhat different account in the Summary.
} 
Note, $y^{t}$ vppon Fryday, beinge $y^{e} x x^{t h}$. of ffebruary, one sir Raffe a Vane, \& on sir Myles Partryge were both hanged [at] ye Tower hyll vppon $y^{\mathrm{e}}$ gallowes, \& sir Mihell Stanhope \& sir Thomas Arundell were beheaded vppon $y^{\mathrm{e}}$ skaffold ther : all wh. foure were condempned by vertue of $\mathrm{y}^{\mathrm{e}}$ acte of vnlawfull assembles as accessaryes to $\mathrm{y}^{\mathrm{e}}$ cluke of Somerset. ${ }^{1}$

Note, $\mathrm{y}^{\mathrm{t}}$ vppon good Frydaye $\mathrm{y}^{\mathrm{e}} \mathrm{xv}^{\mathrm{th}}$. of Aprell $\mathrm{y}^{\mathrm{e}}$ parlyament was cleane dyssolued $\&$ broken vpp, wherin were many goodly lawes \& statutes ordeyned \& stablyshed.

2 The third day of August in a towne called Myddelton Stony in Oxford, there was borne a double child, whiche was two children from $\mathrm{y}^{\mathrm{e}}$ brest vpwarde, in all partis perfyte $\mathrm{w}^{\mathrm{t}}$ one body, one navle, $\&$ one ishew where out passýd both ordure \& water, havynge ij. legges growynge out of $\mathrm{y}^{\mathrm{e}}$ one syde of $\mathrm{y}^{\mathrm{e}}$ belye, $\&$ one $\mathrm{y}^{\mathrm{e}}$ other, one lege havynge ij. bones in one skyne, ix. toes, \& ij soles of $y^{\mathrm{e}}$ foote, callyd \& christenyd by $\mathrm{y}^{\mathrm{e}}$ mydwyfe Johan Joane : thone always slepynge whiles $y^{\mathrm{e}}$ othar was wakynge, in August anno 1552. ${ }^{3}$

Also in $y^{\mathrm{e}}$ same monythe of August began to gooe forwarde $\mathrm{y}^{\mathrm{e}}$ great provysyon for $y^{\mathrm{e}}$ poore, towards $\mathrm{y}^{\mathrm{e}}$ whiche every man was tributorie \& gave a certayn wykelye, \& also somewhat to begyne $y^{\mathbf{e}}$ same on hande : ye first hous which was begon was $y^{\mathrm{e}}$ graye fryers in Newgate market, wh. wente forwarde $w^{t}$ all spede. '

Mihelmas daye, 1552.

George Barnes, habardashar, mayre, $y^{\mathrm{e}} 6$ yere of Ed. 6.

Be yt remembryd $y^{t}$ at this mychelmas $y^{e}$ lorde Wyllyam Hawarde was apoynted to be cleputie of Calice, \& $y^{\mathrm{e}}$ lorde Willoghby was commaundyd home, \& $y^{\mathrm{e}}$ lorde Gray of Wylton was made leftenaunte of Gwynes.

Vpon $y^{e}$ Sondaye, beynge $y^{e}$ xvj. daye of Julii, Nycholas Rydley,

I Summary: "Scaffold, which fowre wer condemned as accessary in that whyche the Duke was condemned for."

2 Stow resumes copying.

3 In the Summary this monster is described somewhat differently; it lived eighteen days.

- Summary. 
byshope of London, made a sermon at Poules crosse, ${ }^{1} \&$ ther declared $\mathrm{y}^{\mathrm{t}} \mathrm{y}^{\mathrm{e}}$ twoo systers, $\mathrm{y}^{\mathrm{e}}$ lady Mary, \& $\mathrm{y}^{\mathrm{e}}$ lady Ellisabeth were both basse borne, $\&$ ther fore were not naturall chyldren vnto kynge Henry $y^{\mathrm{e}}$ eyghte,but borne incest : by reason wherof $\mathrm{y}^{\mathrm{e}}$ lawes both of $y^{\mathrm{e}}$ reallme $\&$ also $\mathrm{y}^{\mathrm{e}}$ ciuille lawe doth not allowe or permite any soche chyldren so borne : \& for $\mathrm{y}^{\mathrm{e}}$ same shewed $\mathrm{y}^{\mathrm{e}}$ wordes of $\mathrm{y}^{\mathrm{e}}$ ciuile lawe.

Neuerthelesse, thankes be to God, the Wednysday, beynge $y^{\mathrm{e}}$ $\mathrm{xix}^{\text {th }}$ of Jully, at $\mathrm{v}$. of $\mathrm{y}^{\mathrm{e}}$ clocke in $\mathrm{y}^{\mathrm{e}}$ afternone $\mathrm{y}^{\mathrm{e}}$ hole body of $\mathrm{y}^{\mathrm{e}}$ counsel, wh. were lefte behynd in $\mathrm{y}^{\mathrm{e}}$ Tower, assembled at Baynardes castell, \& ther communed $\mathrm{w}^{\mathrm{t}} \mathrm{y}^{\mathrm{e}}$ erle of Penbroke, \& ymedyatly came into Chepesycle $w^{\mathrm{t}} \mathrm{y}^{\mathrm{e}}$ kynge of heraudes, wher they proclaymed $\mathrm{y}^{\mathrm{e}}$ vertuous lady Mary, doughter of quene Kateryn, quene of England, ffraunce \&c., ${ }^{2}$ in earth $y^{\mathrm{e}}$ supreme heade : $\mathrm{y}^{\mathrm{e}}$ Joye wherof wonderfull, for some caste money abrod, \& some made bonfyars thorowe $\mathrm{y}^{\mathrm{e}}$ whole cyte : $y^{\mathrm{e}}$ prayses were geuen to God in $\mathrm{y}^{\mathrm{e}}$ churches $w^{\mathrm{t}}$ te deum \& orgaynes, belles ryngynge \& euery wher $\mathrm{y}^{\mathrm{e}}$ tables spredd in $y^{\mathrm{e}}$ stretes, meate \& drynke plentye, wyne geuen ffrely of many men, and a greate peale of ordynaunce was shote of at $y^{e}$ Tower.

After thes thinges thus done, euen $y^{\mathrm{e}}$ sellfe same xix. ${ }^{\text {th }}$ daye of July at ix. of $y^{\mathrm{e}}$ clocke in $\mathrm{y}^{\mathrm{e}}$ nyghte, $\mathrm{y}^{\mathrm{e}}$ erle of Arundell $\mathrm{w}^{\mathrm{t}} \mathrm{y}^{\mathrm{e}}$ lord Patchet rode to $\mathrm{y}^{\mathrm{e}}$ quenes grace to fframyngham, ${ }^{3} \&$ as $\mathrm{y}^{\mathrm{e}}$ was sayd caryed $w^{t}$ them $y^{\mathrm{e}}$ greate sealle of England, \& then also $y^{\mathrm{e}}$ counsell sent letters vnto $y^{\mathrm{e}}$ duke of Northumberland $\mathrm{w}^{\mathrm{t}}$ his adherentes to retyre, $\&$ proclayme $y^{\mathrm{e}}$ quene in his campe : $\mathrm{y}^{\mathrm{e}}$ wh. thynge done he returned homeward, \& at Cambrydge was taken \& commytted to warde. $\mathrm{Y}^{\mathrm{e}} 21$ of July, beynge ffrydaye, $\mathrm{y}^{\mathrm{e}}$ byshope of London, who before prechyd so abhomynabillye, $\mathrm{y}^{\mathrm{e}} \mathrm{xvj}^{\mathrm{th}}$ of July, rode erly $\mathrm{y}^{\mathrm{e}}$ same 21 day in $\mathrm{y}^{\mathrm{e}}$ morninge towardes her grace, to submyte hym vnto her gracious mercy.

1 The other hand resumes.

Stow in the Summary quotes thus far from 'assembled', but ends: ' and Irelande, defendour of the faythe etc'. In the Annales, I033, he substitutes an account closely resembling that in Wriothesley, Chron. ii. 88. Wriothesley says that the style of the proclamation could not be heard for the cheering.:

3 Framlingham. 
And vpon Thursdaye, beinge $y^{e} 21$ of Julii, $y^{e}$ duke of Northumberland havynge receyved $y^{\mathrm{e}}$ sayd proclamacion from $\mathrm{y}^{\mathrm{e}}$ lordes, he returned $\mathrm{y}^{\mathrm{e}}$ same nyghte to Cambridge, $\&$ ther proclamed her grace quene of England; \& $\mathrm{y}^{\mathrm{e}}$ same nyghte after he was layed in his bede $\mathrm{y}^{\mathrm{e}}$ garde came $\&$ seased vppon his weapons $\&$ his body $\&$ tooke hym in charge : \& $\mathrm{y}^{\mathrm{e}}$ next day $\mathrm{y}^{\mathrm{e}}$ lord erle of Huntyngton, $\mathrm{y}^{\mathrm{e}}$ lorde Graye, \& dyuers other, \& $\mathrm{y}^{\mathrm{e}}$ capeteyne of $\mathrm{y}^{\mathrm{e}} \operatorname{gar}[\mathrm{de}]^{1}$ also were arested by $\mathrm{y}^{\mathrm{e}}$ quenes commaundement.

And vppon Sonday, beinge $y^{\mathrm{e}} 22$ daye of Julye, as it was sayd, dyuerse of $y^{\mathrm{e}}$ lordes of $\mathrm{y}^{\mathrm{e}}$ counsell here rode towardes her grace. Vppon Tewesdaye, beinge $y^{e} x_{x v^{t h}}$. day of July in $y^{e}$ feast of sainte James thapostell, aboute iiij. of $y^{e}$ clocke at afternone thes persons followynge were broughte as prysoners into $\mathrm{y}^{\mathrm{e}}$ Tower of London, $\mathrm{y}^{\mathrm{t}}$ is to saye $\mathrm{y}^{\mathrm{e}}$ duke of Northumberland, $\mathrm{y}^{\mathrm{e}}$ erle of Warwyke his sonne, sir Ambrose Dudleye his sonne, \& Harry Dudley his sonne, therle of Huntyngton, \& $y^{e}$ lorde Hastinges his sonne, one [ ] Sandes ${ }^{2}$ a prest of Cambrydge, who had preched in Cambrydge in all condycions \& rather worse than $y^{\mathrm{e}}$ bishope of London, Sir John Gaates capteyne of $y^{e}$ garde, \& Harry Gaates his brother, Sir Androwe Dudley, \& sir Thomas Pallmer.

And $y^{\mathrm{e}}$ morrow after, beynge Wednysdaye $y^{\mathrm{e}} 26$ of $\mathrm{July}^{3}{ }^{3}$ ther were broughte into $\mathrm{y}^{\mathrm{e}}$ Towre the prisoners folowynge, The lord marques Northeampton, The byshope of London, Rydleye, sir Richard Corbyt knyt of Suffolke, \& a serchar of Gravesende called Harmonde. Thes came in at Allgate. And $y^{e}$ same nyght $y^{e}$ two cheff Judgys of England, $\mathrm{y}^{\mathrm{e}}$ lord Mountagwe, cheff judge of $\mathrm{y}^{\mathrm{e}}$ comon place, \& syr Rogar Cholmley, cheffe justice of $\mathrm{y}^{\mathrm{e}}$ kyngs benche were bothe comytted to $y^{\mathrm{e}}$ Towre. And neverthelesse they were sone delyveryd, beyng fynyd at serten somes of money.

Vpon Fryday $y^{\mathrm{e}}$ xxviij. day of Julii the duke of Suff., Mster. Cheeke, whiche was $y^{\mathrm{e}}$ kynges schole-mastar, $w^{\mathrm{t}}$ divers othar, were commytted to $\mathrm{y}^{\mathrm{e}}$ Tower.

1 MS., 'game.'

2 Dr Edwin Sandys, the Vice-Chancellor of Cambridge. The MS. is damaged.

3 Stow resumes copying. 
Vpon Thursday, beynge $y^{e}$ thyrd of August, $y^{e}$ quenes grace, ladie Marie, came aboute vij. of $\mathrm{y}^{\mathrm{e}}$ cloke at nyght vnto $\mathrm{y}^{\mathrm{e}}$ Towre of London, \& vpon her awayted a great nomber of soldyours, some in blewe, some in white \& grene, \& some in Redde cottes, \& a ix. C. shott of ordynaunce was shott of $y^{\mathrm{e}}$ Towre.

And at hyr entrynge into hir great chambar $y^{\mathrm{e}}$ bishope of Wynchester, doctour Gardenar, $\mathrm{y}^{\mathrm{e}}$ duke of Northeffolke, \& $\mathrm{y}^{\mathrm{e}}$ douches of Somersett, \& myster Courtneye, sonn to $\mathrm{y}^{\mathrm{e}}$ marquess of Exceter, had theyr pardon grauntyd vnto them by hyr graces owne mouthe.

Vppon Sattarday, beynge $y^{\mathrm{e}} \mathrm{v}$. of August, $\mathrm{y}^{\mathrm{e}}$ byshope of London, doctour Bonar, who hadd lyen in $\mathrm{y}^{\mathrm{e}}$ Marchallse aboute $\mathrm{v}$. yeres, was delyveryd \& set at lybertie. And doctour Tunstall, byshope of Duresme, was also delyveryd out of $y^{\mathrm{e}}$ Towre.

Vppon Twesclaye, $\mathrm{y}^{\mathrm{e}}$ viij. of August, $\mathrm{y}^{\mathrm{e}}$ corps of kynge Edward $\mathrm{y}^{\mathrm{e}} \mathrm{vj}$. was buryed in $\mathrm{y}^{\mathrm{e}}$ churche of sent Petar at Westmyster. And $\mathrm{y}^{\mathrm{e}}$ nyght before ther was placebo \& dyrige sayd in latyn before $\mathrm{y}^{\mathrm{e}}$ quene $w^{t} y^{n} y^{\mathrm{e}}$ Towre $: \&$ this present Twesdaye ther was a messe of requyem songe in latin before $\mathrm{y}^{\mathrm{e}}$ quene by $\mathrm{y}^{\mathrm{e}}$ byshope of Wynchestar $w^{t}$ in $y^{e}$ Towre.

On Twesdaye beynge $y^{e}$ xxij. daye of Auguste, The Duke of Northumberland, sir John Gaates, \& buskynned Palmer were all thre behedyd vppon $\mathrm{y}^{\mathrm{e}}$ skaffolde at $\mathrm{y}^{\mathrm{e}}$ Towr hyll.

The xxvij. of August, beynge Sondaye, $y^{e}$ bakesyde of $y^{e}$ highe altar of Powles churche beynge made up $\mathrm{w}^{\mathrm{t}}$ brike some what above an altar but not clearly fynyshed, ther was hyghe masse songe in lattyn $\mathrm{w}^{\mathrm{t}}$ bothe mattyns \& evensonge lykewyse in lattyn. And dyvers churches in London had $y^{\mathrm{e}}$ lyke servyce.

Vppon Satterday, beynge $\mathrm{y}^{\mathrm{e}}$ laste daye of September, $\mathrm{y}^{\mathrm{e}}$ quenes highnes rode through $\mathrm{y}^{\mathrm{e}}$ citie in moaste goodly manere. The pageauntes in all places accustomyd beynge moste gorgyously trymmyd: amongest all $\mathrm{y}^{\mathrm{e}}$ thre pagauntes made by $\mathrm{y}^{\mathrm{e}}$ straungers wer $y^{\mathrm{e}}$ myghtyest, wher of thone made by $\mathrm{y}^{\mathrm{e}}$ Gennayes $^{1}$ at Fanchurche, the othar at Grasechurche made by $y^{\mathrm{e}}$ Stilliardes, \& $\mathrm{y}^{\mathrm{e}}$

\section{Genoese.}


third in $y^{\mathrm{e}}$ myddes of Gracious streate made by $\mathrm{y}^{\mathrm{e}}$ Florentynes were all made $\mathrm{w}^{\mathrm{t}}$ gattes to passe throwghe, \& $\mathrm{y}^{\mathrm{e}}$ buyldynges wer very highe statlye. And so hir grace passyd forthe vnto Westmyster, \& as she passyd by Pawles a certayne duche man stode vpon $\mathrm{y}^{\mathrm{e}}$ wetharcoke $w^{t}$ a flagge in his hande, $\&$ ondar hym vpon $y^{e}$ crosse a skaffolde $\mathrm{w}^{\mathrm{t}}$ flaggs, \& ondar $\mathrm{y}^{\mathrm{t}}$ vpon $\mathrm{y}^{\mathrm{e}}$ ball an othar skaffolde $\mathrm{w}^{\mathrm{t}}$ flaggs \& streamers. ${ }^{1}$

Vpon Sonday, beynge $\mathrm{y}^{\mathrm{e}}$ fyrste day of October, $\mathrm{y}^{\mathrm{e}}$ quenes grace was crownyd at Westmystar, \& before here went all $\mathrm{y}^{\mathrm{e}}$ byshoppes $\mathrm{w}^{\mathrm{t}}$ myters $\&$ croysers, $\& \mathrm{y}^{\mathrm{e}}$ clerks syngynge $\mathrm{y}^{\mathrm{e}}$ servyce all in lattyn.

Vpon Thursdaye, beynge $\mathrm{y}^{\mathrm{e}} \mathrm{v}$. day of October, $\mathrm{y}^{\mathrm{e}}$ barge of Gravesend by greate mysfortune of a catche comynge vpon hir was ovarthrowne and aboute fortye persons drownyd ${ }^{2}$ : our lord be merciful to them.

On Monday, beynge $\mathrm{y}^{\mathrm{e}} \mathrm{xxiij}$., on wednysday $\mathrm{y}^{\mathrm{e}} \mathrm{xxv} .$, \& Fryday, beynge $y^{\mathrm{e}}$ xxvij. day of October, were certayne dysputacions in $\mathrm{y}^{\mathrm{e}}$ longe ${ }^{3}$ chapell at $y^{\mathrm{e}}$ northe doore of Paules concernynge $y^{\mathrm{e}}$ transubstanciacion, but no thyng throughely determynyd. ${ }^{4}$

Thomas Whit, marchaunt tayloure, mayie, $y^{\mathrm{e}} \mathrm{xxviij}$. of Octobar, 1553 .

Vpon Fryday ye iij. day of Novembar, 1553, ye aforesaid doucheman, who stode vpon $y^{\mathrm{e}}$ wethercoke at $\mathrm{y}^{\mathrm{e}}$ queens rydynge thrughe London, dyd set up $y^{\mathrm{e}}$ wetharcoke of Poules agayne vpon $y^{\mathrm{e}}$ crosse, whiche he had causyd to be amendyd $\mathrm{w}^{\mathrm{t}}$ a brode rownde vane set vpon $\mathrm{y}^{\mathrm{e}}$ tayle to thend $\mathrm{y}^{\mathrm{t}}$ she myght turne $\mathrm{w}^{\mathrm{t}}$ every wynde, \& even $\mathrm{y}^{\mathrm{e}}$ same day he stroke downe both $\mathrm{y}^{\mathrm{e}}$ skafoldes, whiche he before had made agaynst $y^{\mathrm{e}}$ queens comynge.

Vpon Wednysday $y^{\mathrm{e}}$ viij. of Novembar an obyt was kept in Poules

1 Stow uses this paragraph, but omits 'amongest' to 'statlye, ' and varies the last clause. In the Annales he follows The Chronicle of Queen Jane and Queen Mary, pp. 27-30.

2 Summary but ending: "and xiiii. persones drowned, and xvj. saued by swymmyng."

So Stow. The MS. has "londe."

- Summary. 
for doctour Dolman,\& vpon Thursday $\mathrm{y}^{\mathrm{e}} \mathrm{ix}$. of Novembar $\mathrm{y}^{\mathrm{e}}$ byshope of London songe $\mathrm{y}^{\mathrm{e}}$ masse hymselfe.

Vpon Monday, beynge $y^{\mathrm{e}}$ xiij. day of Novembar, The archebyshope of Cantourbery, the lord Robert Dudleye, the lord Guylforde Dudley, husbond of $\mathrm{y}^{\mathrm{e}}$ lady Jane pretendyd quene, the lord Henrie Dudley, youngest sone of $\mathrm{y}^{\mathrm{e}}$ sayd thre Dudleyes, and $\mathrm{y}^{\mathrm{e}}$ sayd lady Jane $\mathrm{y}^{\mathrm{e}}$ pretendyd queene, were all $\mathrm{v}$. arreygnyd at $\mathrm{y}^{\mathrm{e}}$ Guylde hawll vpon highe treason, \& so cast $\&$ adiudgyd to be drawne, hangyd, $\&$ quarteryd.

Vpon Satterday, beynge $y^{\mathrm{e}} \mathrm{xxv}$. of Novembar, \& $\mathrm{y}^{\mathrm{e}}$ yere of our lord 1553, Anno I. Regyne Marie, at vj. of $\mathrm{y}^{\mathrm{e}}$ cloke at night S. Katheryns lyghts were cryed aboute $\mathrm{y}^{\mathrm{e}}$ battylments of Paules steple, whiche had not ben many yeres before.

Vpon Tewesdaye or Wednysdaye $\mathrm{y}^{\mathrm{e}} \mathrm{v}$. of Decembar, $\mathrm{y}^{\mathrm{e}}$ parlyament was dissolvyd, wherein was repeallyd ix. servall actes, viz. for mariage of priestes, $\mathrm{y}^{\mathrm{e}}$ legitimacion of prestis children, $\mathrm{y}^{\mathrm{e}}$ receyvynge of $\mathrm{y}^{\mathrm{e}}$ sacrament in bothe kyndes, $\mathrm{y}^{\mathrm{e}}$ makynge of deacons \& pristes, the vniformytie of devyne prayer, the pluckynge downe of altars, Roods, \& Images, the observacion of holydayes \& fastynge dayes, $w^{t}$ ij. othar actes.

Vpon $y^{\mathrm{e}} 14$ day of Januarye, 1553, $\mathrm{y}^{\mathrm{e}}$ lord chauncelour $\mathrm{w}^{\mathrm{t}}$ othar of $\mathrm{y}^{\mathrm{e}}$ counsell declaryd openly vnto $\mathrm{y}^{\mathrm{e}}$ queens Maiestie howseholde $\mathrm{y}^{\mathrm{t}}$ ther was a mariage concludyd betwene hir grace $\& \mathrm{y}^{\mathrm{e}}$ kynge of Spayne, ${ }^{2}$ whiche was $y^{\mathrm{e}}$ fyrst tyme it was certaynly knowne abrode.

Aboute $y^{e}$ xxv. day of Januarie, Anno 1553, anno primo Regine Marie, began $y^{\mathrm{e}}$ comocion in Kent, $\mathrm{y}^{\mathrm{e}}$ cheffe captayns wherof was sir Thomas Wyat \& one syr Henrie Illisleye ${ }^{3}$ : but it was sayd $\mathrm{y}^{\mathrm{t}}$ lorde Cobham had taken parte $w^{t} y^{e}$ queene: the cause of theyr

1 Summary in Stow's own words.

2 Summary reading: ' $\mathrm{xx}$. day of January.' The emperor's ambassadors had public audience of the queen on $14^{\text {th }}$ January, $\&$ the queen's decision was communicated to the lord mayor next day. In the Annales this is given correctly from The Chronicle of Queen Jane and Queen Mary pp. 34, 35.

3 Isley, Stow. 
comocion (as $y^{\mathrm{e}}$ brute went) was because they woulde not be subiecte to $\mathrm{y}^{\mathrm{e}}$ kynge of Spayne: for thappesynge where of ther was a great nombar of men made out of $\mathrm{y}^{\mathrm{e}}$ citie of London, \& all $\mathrm{y}^{\mathrm{e}}$ companyes chargyd ther $\mathrm{w}^{\mathrm{t}}$.

And vppon Candelmas day, beynge Frydaye $\& y^{\mathrm{e}} \mathrm{ij}$. day of Februarie, all $\mathrm{y}^{\mathrm{e}}$ aldarmen of London $\& \mathrm{y}^{\mathrm{e}}$ inhabytauntes of every warde were $\mathrm{y}^{\mathrm{e}}$ whole day in harnes for feare of $\mathrm{y}^{\mathrm{e}}$ aforesayde Rebells, who as it was sayd approchid : \& my lord mayre was at Ledyn hall $\mathrm{w}^{\mathrm{t}}$ a great nomber of men in harnesse, whiche were apoyntyd forthe by $\mathrm{y}^{\mathrm{e}}$ companyes of $\mathrm{y}^{\mathrm{e}}$ citie, double so many as before, for wher $\mathrm{y}^{\mathrm{e}}$ marchaunt taylours at $\mathrm{y}^{-\mathrm{e}}$ fyrst tyme armed $\mathrm{xxx}$. at this tyme they armyd lx. \&c.

Vppon Satterday, beynge $y^{\mathrm{e}}$ iij. day of February, $\mathrm{y}^{\mathrm{e}}$ morow after Candelmas day, s. Thomas Wyatt, who had lyen at Grenewitche by $\mathrm{y}^{\mathrm{e}}$ space of ij. nyghts $\&$ a daye, cam sodeynly aboute one of $\mathrm{y}^{\mathrm{e}}$ cloke at aftar none into Sothewarke $w^{t}$ his band of men, whose sodayne comynge drave $y^{e}$ citizens into great feare so that they were fayne to close vp $y^{\mathrm{e}}$ gatte on $\mathrm{y}^{\mathrm{e}}$ brydge, \& cutt downe $\mathrm{y}^{\mathrm{e}}$ draw brydge $\&$ let it fawll in to $\mathrm{y}^{\mathrm{e}}$ watar, $\&$ all men ran to harneys for $\mathrm{y}^{\mathrm{e}}$ deffence of $y^{e}$ citie. How be it sir Thomas Wyatt made to ${ }^{1}$ proffer of entrie, but went streyght wayes to worke \& his men $w^{t}$ hym \& trenchid Sothewarke at every end, and plantyd his ordenaunce for his deffence. The citizens in $y^{\cdot e}$ meane season preparynge great watche \& warde. And thus lay syr Thomas Wyat from ye Satourday at noone vntyll shrove Tewesday in $\mathrm{y}^{\mathrm{e}}$ mornynge next folowynge. The queens maiestie durynge this tyme preparyd greate power to goo agaynst hyme. The aforesayd shrovetewesday, beynge $\mathrm{y}^{\mathrm{e}} \mathrm{vj}$. day of Februarie, early in $y^{\mathrm{e}}$ mornynge $\mathrm{y}^{\mathrm{e}}$ sayd syr Thomas Wyate removyd all his people $\&$ theyr ordynaunce all save one pece, $\&$ went vnto Kyngston, \& ther beyng sumwhat resysted at $y^{\mathrm{e}}$ last he by entreatie passyd $y^{\mathrm{e}}$ brydge, whiche brydge was by hyme $\&$ his foarcyd $\&$ made, for $y^{\mathrm{e}}$ brydge $\mathrm{y}^{\mathrm{t}}$ before was ther was cutt downe or he cam : \& then he marchyd to London wardes a bowght xij. of

1 So MS.; read ' no'. 
$y^{\mathrm{e}}$ cloke at nyght. Vpon $\mathrm{y}^{\mathrm{e}}$ morow, beynge ashwednysdaye, aboute thre of $\mathrm{y}^{\mathrm{e}}$ cloke in $\mathrm{y}^{\mathrm{e}}$ mornynge a greate outcrye was made thrughe London $\mathrm{y}^{\mathrm{t}}$ every man shuld put on his harnysse, $\&$ as sone as it was day lyght ye wardars, whiche were apoyntyd to have wardyd at $\mathrm{y}^{\mathrm{e}}$ bridge, were for $\mathrm{y}^{\mathrm{e}}$ moast parte all sent to Ludgate $\&$ othar placis. The queenes armye in $\mathrm{y}^{\mathrm{e}}$ meane season encampyd them selves in $\mathrm{y}^{\mathrm{e}}$ fylde before $\mathrm{y}^{\mathrm{e}}$ place callyd saynt James beyonde Westmyster, whithar it was sayd $y^{\mathrm{e}}$ rebells purposyd to come : and aboute two of $\mathrm{y}^{\mathrm{e}}$ cloke they came : the queens ordynaunce was schott of, \& $y^{\mathrm{e}}$ horsemen marchyd fortheward, \& set vpon them : $\&$ sir Thomas Wyate perseyvynge his dystruction at hand devysyd $\mathbf{w}^{t}$ hym selffe this pollicie : he $\mathrm{w}^{\mathrm{t}}$ a certayne nombar slyppyd bye, $\&$ havynge theyr swerds drawne cam in at $\mathrm{y}^{\mathrm{e}}$ Temple barre cryenge, God save quene Marie : $y^{\mathrm{e}}$ people, knowynge hym not to be Wyatt, sufferyd hym $\mathrm{w}^{\mathrm{t}}$ his companye to entre, thynkynge them to have bene some of theyr frynds : \& ymediatly pursuite was made aftar hym by $\mathrm{y}^{\mathrm{e}}$ quenes armye, and in Fletstrete he was taken $\&$ dyvers othar $w^{\mathrm{t}}$ hym, as two of $\mathrm{y}^{\mathrm{e}}$ Knayvatis, ${ }^{1} \&$ two of $\mathrm{y}^{\mathrm{e}}$ Cobhams, Captayne Brett, ${ }^{2}$ whiche went away $\mathrm{w}^{\mathrm{t}} \mathrm{y}^{\mathrm{e}}$ Londoners at Rochestar. Thar was slayne aboute $y^{\mathrm{e}}$ numbar of an hondred ${ }^{3}$ of $y^{\mathrm{e}}$ Rebells. And then $\mathrm{y}^{\mathrm{e}}$ quene of hir clemencie $\&$ pitie grauntyd pardon to all $\mathrm{y}^{\mathrm{e}}$ rest of theyr lyves: and aftar a day or two syr Henry Isley $w^{t}$ dyvers othar were brought vnto $\mathrm{y}^{\mathrm{e}}$ Towre.

Vpon Monday, beynge $y^{\mathrm{e}} \mathrm{xij}$. day of Februarie, $\mathrm{y}^{\mathrm{e}}$ lorde Gylforde Dudley, forthe sonne to $\mathrm{y}^{\mathrm{e}}$ duke of Northumbarland, hosband to $\mathrm{y}^{\mathrm{e}}$ lady Jane, pretendyd quene, was behedyd at $\mathrm{y}^{\mathrm{e}}$ Towre hyll : and $\mathrm{y}^{\mathrm{e}}$ sayd day lady Jane, $\mathrm{y}^{\mathrm{e}}$ pretendyd queene, was behedyd $\mathrm{y}^{\mathrm{e}}$ same day $\mathrm{w}^{\mathrm{t}}$ in $\mathrm{y}^{\mathrm{e}}$ Towre. Abought two days afore $\mathrm{y}^{\mathrm{e}}$ duke of Suffolke $\mathrm{w}^{\mathrm{t}}$ one of his brythern, whiche before fledd to Lester, ther to rays

1 Knyvet or Knevet. The Chronicle of Quecn Jane and Queen Mary p. 50 mentions William Knevet and Thomas Cobham as taken prisoners here; other prisoners were Thomas Knevet, Anthony Knevet, George Cobham and Sir William Cobham.

2 Alexander Brett; see Chron. Q. Jane, pp. 38, 5 I.

3 ' hondred' was afterwards struck out, and ' $\mathrm{xx}$ ' written above. 
$\mathrm{y}^{\mathrm{e}}$ people ther to ayd syr Thomas Wyat, was brought in to $\mathrm{y}^{\mathrm{e}}$ Towre of London.

Vpon $y^{\mathrm{e}}$ sayd Monday, beynge $\mathrm{y}^{\mathrm{e}} \mathrm{xij}$. of Februarie, ${ }^{1} \mathrm{y}^{\mathrm{e}}$ lord Courtney, therle of Devonshire, who was delyveryd out of $y^{\mathrm{e}}$ Towre at $\mathrm{y}^{\mathrm{e}}$ queens entrynge, as is afore sayde, was nowe agayne comytted vnto $\mathrm{y}^{\mathrm{e}}$ Towre. The same Monday ther were gallowes to $\mathrm{y}^{\mathrm{e}}$ nomber of xviij. payre sett vp in dyvers placis of London : as two in Chepesyde, wherof one was beyond $\mathrm{y}^{\mathrm{e}}$ cross towarde Poules, \& thothar almoast at $y^{\mathrm{e}}$ great conduyte : at dyuers of $y^{\mathrm{e}}$ gates othar.

Vpon Wednysday folowynge, beynge $y^{e}$ xiiij. day of Februarie, ther were vj. persons hangyd in Chepe syde vpon $y^{\mathrm{e}}$ two payr of galowes. And vpon thothar gallowes in othar placis of $y^{\mathrm{e}}$ citie to $y^{e}$ nombar of fifftye ${ }^{2}$ persons, whiche wer of $y^{e}$ Londoners $y^{t}$ were set out by $y^{\mathrm{e}}$ citie and rane away from $y^{\mathrm{e}}$ duke of Northfolke vnto Wyatt, \& wer taken in ye fylde vpon ashewednesday.

Also $\mathrm{y}^{\mathrm{e}}$ Sonday before, ${ }^{3}$ Captayn Bret $\mathrm{w}^{\mathrm{t}} \mathrm{xxv}$. more wer layd in a cart in Sothewarke by ser Robert Sothewell,shrive of Kent, $y^{\mathrm{e}}$ whiche wer asygnyd to be executyd in dyver placis in Kent, but many of them were aftarward pardonyd.

Vpon Thursday, beynge $\mathrm{y}^{\mathrm{e}} \mathrm{xxj}$. $^{4}$ day of Februarie, $\mathrm{y}^{\mathrm{e}}$ remaynante of $y^{\text {e }}$ saycle rebells, whiche hadd bene emprisonyd, some in Newgate, some in the Countars, some in Sothewarke, \& some in seynt Petars chirche at Westmystar in dyvers chapells ther, whiche wer to $\mathrm{y}^{\mathrm{e}}$ nomber of $\mathrm{xij}$. score persons or more, were brought to $\mathrm{y}^{\mathrm{e}}$ crosse in Chepe, where $y^{\mathrm{e}}$ quenes mercifull pardon was declaryd vnto them to theyr great comfortes. ${ }^{3}$

1 So also Chron. Queen Jane and Queen Mary, p. 59 and Stow, Annales 1052. But Stow. Summary, and Wriothesley, Chron. ii. I 13 have $5^{\text {th }}$ March.

${ }^{2}$ Machyn, Diary, p. 55 gives 46. Grafton (ii. 543) says 50. Other chronicles smaller numbers.

${ }^{3}$ Machyn and Wriothesley (ii. I12) give $18^{\text {th }}$ February, which was the Sunday after.

4 Should be 'xxij.'

3 Summary somewhat differently, with date $23^{\text {rd }}$ February. 
And vpon Fryday, beynge $y^{\mathrm{e}} \mathrm{xxij}^{1}{ }^{1}$ of Februarie, the duke of Suffolke was beheaded at $y^{\mathrm{e}}$ Towre hyll.

Vpon Thursday, beynge $y^{\mathrm{e}}$ viij. day of Marche, tharchbisshope of Cantorbery, $y^{\mathrm{e}}$ byshope of London, Nycholas Rydleye, \& fathar Latymer were brought out of $\mathrm{y}^{\mathrm{e}}$ Towre, $\&$ sent vnto Oxforde, ther to remayne vntyll $y^{\mathrm{e}}$ queens comyng thethar at $\mathrm{y}^{\mathrm{e}}$ parlyament, beynge appoyntyd to begyn vpon $y^{\mathbf{e}}$ Monday aftar lowe Sonday, $\mathrm{y}^{\mathrm{e}} \mathrm{iij}^{2}$ day of Aprill; \& $\mathrm{y}^{\mathrm{e}}$ tearme also was apoynted to be kepte at Oxford lykewysse.

Vpon Saterday, beynge $y^{\mathrm{e}} \mathrm{xvij}^{{ }^{3}}$ of Marche, $\mathrm{y}^{\mathrm{e}}$ lady Elisabeth, doughter of quene Anne Bulleyne, was comyttyd vnto $y^{\mathrm{e}}$ Towre.

Wheras $\mathrm{y}^{\mathrm{e}}$ parlyament $\&$ tearme were bothe appoyntyd to have bene kepte at Oxenforde, it was now reiournyd vnto London by proclaymacion, and began at Westmystar $y^{\mathrm{e}}$ second day of Apryll, beynge Monday.

Vpon Wednysday, beynge $\mathrm{y}^{\mathrm{e}} \mathrm{xj}_{\text {: }}$ of Aprill, sir Thomas Wyat, capitayne \& ryngledar of $\mathrm{y}^{\mathrm{e}}$ sayd Rebells, was behedyd at $\mathrm{y}^{\mathrm{e}}$ Towr hyll.

Vpon $y^{\mathrm{e}} \mathrm{xxvij}$. day of Apryll one Nicholas Thokmorton, ${ }^{4}$ a gentylman, was arraygnyd at $y^{\mathrm{e}}$ Gyldhall as accessarye vnto Wyats conspiracie, \& vpon his quest were chosen dyvers sytysyns, one was Whetstone, ${ }^{5}$ haberdashar, Emanuell Lucas, ${ }^{6}$ marchant taylor, Watur Yonge, Mst. Baskerfylde, Symon Lowe, Wyliam Bankes, Mstar. Poyntar, Mst. Martyn, and fowr othars, whiche dyd acquyt hym, and shortly aftar sent for before $y^{\mathrm{e}}$ connsell, $\& \mathrm{ij}$. of them sent to $y^{\mathrm{e}}$ Towre, $\mathrm{y}^{\mathrm{e}}$ rest were sent to $\mathrm{y}^{\mathrm{e}}$ Flete.

Vpon Fryday, beynge $y^{\mathrm{e}}$ xviij. day of May, one Wylyam Thomas, a gentylman who had bene clarke of $\mathrm{y}^{\mathrm{e}}$ counsell, who had bene $\mathrm{w}^{\mathrm{t}}$ Wyat, and allso detarmynyd to have slayne $y^{\mathrm{e}}$ quene $\mathrm{w}^{\mathrm{t}}$ a dagar,

1 Should be 'xxiij.'

2 Should be 'ij.'

3 Other authorities give Palm Sunday, $18^{\text {th }}$ March.

4 Throckmorton. He was arraigned on $17^{\text {th }}$ April, and acquitted on the $25^{\text {th }}$.

${ }^{5}$ See Holinshed IV. 3I, 64, 74 for the jurors, and $3 \mathrm{I}-54$ for the record of the trial.

6 Lucare, Wriothesley. 
was drawne from $y^{\mathrm{e}}$ Towre of London to Tyborne, $\&$ ther hangyd $\&$ quarteryd.

Vpon Satarday, beynge $y^{e} x i x$. day of May, $y^{e}$ lady Elizabeth was brought out of $\mathrm{y}^{\mathrm{e}}$ Towr, \& so convayed by watar vnto Rychemonde, $\&$ from thence $y^{\mathrm{e}}$ next day she went to Wyndsore, \& so by my lord Wyllyams to Rycote in Oxenfordeshire, \& from thens to Wodstoke, where as it was sayd she shuld remayne. ${ }^{1}$

The fyrste ${ }^{2}$ day of June $y^{e}$ gallowsys in London were commandyd to be takyn downe, whiche thynge was done accordyngly.

And aboute $y^{\mathrm{e}}$ sayd fyrst ${ }^{3}$ day of June ther was grauntyd by acte of comon counsell a fyvtyne $\&$ a halfe to be levyed of $y^{\mathrm{e}}$ citezens for $\mathrm{y}^{\mathrm{e}}$ gyldynge of $\mathrm{y}^{\mathrm{e}}$ crosse in Chepe, \& for makynge of pagauntes agaynst $\mathrm{y}^{\mathrm{e}}$ comynge of $\mathrm{y}^{\mathrm{e}}$ prynce of Spayne; $\&$ ther vpon skaffolds were made aboute $y^{\mathrm{e}}$ crosse, $\&$ werkemen set a werke for makynge of $\mathrm{y}^{\mathrm{e}}$ pagauntis.

Vpon Sonday, beynge $y^{\mathrm{e}} \mathrm{xv}$. day of Jully, 1554, \& anno Regine Marie secondo, a yonge wenche ${ }^{4}$ of $y^{e}$ age of $x v j$. or $x v i j$. yeres dyd open penaunce at Poules crosse, standynge vpon a skaffolde all $\mathrm{y}^{\mathrm{e}}$ sermon tyme, \& confessyd hir falte openly: that she beynge intysed by lewde counsell had ${ }^{5}$ counterfetyd certayne speaches in an house in Alclarsgate strete, about $y^{\mathrm{e}}$ whiche matar $\mathrm{y}^{\mathrm{e}}$ people were wondarfully molestyd, some saynge $y^{t}$ it was a sprite that spake in a wall. some one thynge, some an othar : on this manor she vsed hir selffe, she lay in hir bed, \& whistelyd in a strange whystell made for $y^{\mathrm{e}}$ nones, then was ther (as she confessyd) vj. falce knaves, ${ }^{6}$ whos names she ther declaryd, confecleryd $\mathrm{w}^{\mathrm{t}} \mathrm{hir}$, whiche toke vpon them

1 Summary.

2Summary, 'fowerth'. Machyn, Diary p. $65 \cdot 4^{\text {th }}$ June.

${ }^{3}$ Machyn says $4^{\text {th }}$ June.

- Summary, 'Elizabeth a yonge wenche.' Wriothesley, ii. 117, calls her Elizabeth Crofte.

${ }^{5}$ Summary', 'had vpon the xiiij. day of Marche last passed. Wriothesley ' in Apryll, '

6 Summary, 'iiij. or vj. companions.' Wriothesley and Machyn name one as John Drake, a servant of Anthony Nevill or Anthony Knevett. 
to entarprite what $y^{\mathrm{e}}$ spryt spake, expressynge certayn sedycius ${ }^{1}$ words agaynst $\mathrm{y}^{\mathrm{e}}$ queens hyghnes.

Vpon Satarday, beyng $\mathrm{y}^{\mathrm{e}} \mathrm{xxj}$. of Julii, ther was great Joye \& tryoumpth made in London $\mathrm{w}^{\mathrm{t}}$ bonffyars \& ryngynge for $\mathrm{y}^{\mathrm{e}}$ salffe landynge of $y^{\mathrm{e}}$ prynce of Spayne, who came on land vpon Thursday at nyghte, $\mathrm{y}^{\mathrm{e}} \mathrm{xix}$. of Julii.

Vpon Wedenseday, beynge saynt James day $\mathrm{y}^{\mathrm{e}} \mathrm{xxv}$. day of Julii, at Wynchestar $y^{\mathrm{e}}$ prynce of Spayne was maried vnto $y^{\mathrm{e}}$ queens maiestie.

Vpon Sonday, beynge $y^{\mathrm{e}} \mathrm{xxix}$. day of Julii, one doctour Harpefeld ${ }^{2}$ preachyd at Powles crosse, and after he had made his proposycion he exortyd all men to become newe men bothe in mynd \& doyng, for so myche (sayd he) as I have newe thyngs to declare vnto you and therfore $y^{\mathrm{e}}$ must become newe, for accordynge to Christis saynge no man puttythe newe wyne into olde vessyles etc.; and thervpon he declaryd vnto $\mathrm{y}^{\mathrm{e}}$ people $\mathrm{y}^{\mathrm{e}}$ style in maner folowynge: fyrst I command vnto........ ${ }^{3}$ Philipp and Marye by $y^{\mathrm{e}}$ grace of God kynge \& quene of England, Faunce, Napyles, Jerusalem and Irlande, defender of $\mathrm{y}^{\mathrm{e}}$ faythe, prynces of Hyspayne \& Cicile, archedukes of Austrie, dukes of Mylayne, Burgoyne, \& Brabant, countes of Ausborow, ${ }^{4}$ Flaunders \& Tiroll: \& then procedyd forthe $w^{t}$ his prayer. ${ }^{5}$

Vpon Lamas day, beynge $y^{\mathrm{e}}$ fyrst of August, $\mathrm{y}^{\mathrm{e}}$ proclamacion was made consernynge $y^{\mathrm{e}}$ sayd style in $\mathrm{y}^{\mathrm{e}}$ forenone, and at aftar none $\mathrm{y}^{\mathrm{e}}$ same stylle pryntyd bothe in Englisshe $\&$ in lattyn, was set up in dyvers placis of the citie.

And vpon Satterdaye, beynge $y^{\mathrm{e}} \mathrm{x}$ viij. day of August, ${ }^{6} \mathrm{y}^{\mathrm{e}}$ kynge

1 Summary, 'sedicious and opprobrious.'

2 Nicolas Harpsfield.

3 The edge of the leaf is worn.

- sc. Habsburg.

5 Compare Machyn, pp. 66-7.

- So Stow in the Summary, but in the Annales he gives I $2^{\text {th }}$ August. Wriothesley (ii. 122) has $18^{\text {th }}$ August, and so also Chron. Queen Mary, p. 78. Stow makes only slight use of the account above. 
$\& \mathrm{y}^{\mathrm{e}}$ quene bothe togethar $\mathrm{w}^{\mathrm{t}} \mathrm{ij}$. swerdes borne before them passed ovar London brydge from Suffolke place in Sothewarke, wher they had lyene $\mathrm{y}^{\mathrm{e}}$ nyght before, and so rode bothe togethar thrughe $\mathrm{y}^{\mathrm{e}}$ citie. And at Gracious strete $y^{\mathrm{e}}$ house of $\mathrm{y}^{\mathrm{e}}$ Stylyard at theyr cost made a sumptious $\&$ a large pagaunte fowr square $w^{t}$ stones of dyvars sortis. And at $\mathrm{y}^{\mathrm{e}}$ Stokes ${ }^{1}$ was a great pagaunte made at $\mathrm{y}^{\mathrm{e}}$ cities cost declarynge $\mathrm{y}^{\mathrm{e}}$ nobylytie of iiij. Philyppes, ${ }^{2}$ whiche have excellyd in vertue,\& praysynge ye kynge for $y^{\mathrm{e}}$ fyfthe. At Iremongare lane ${ }^{3}$ ende was an othar greate pageante of Orpheus syttynge on $\mathrm{y}^{\mathrm{e}}$ toppe, playenge on a harpe, and lytyll boyes dressyd lyke wylde beastis dawnsynge aboutes $y^{\mathrm{e}}$ mownt wheron he satt. The crosse beynge newly gyldyde shone very fayre. At $y^{\mathrm{e}}$ lytyll conduite was $\mathrm{y}^{\mathrm{e}}$ whole genelogie of $\mathrm{y}^{\mathrm{e}}$ quenes maiestie \& $\mathrm{y}^{\mathrm{e}}$ kyngs, brought from Edward $y^{\mathrm{e}}$ thyrde, fathar to John of Gaunte : and at $\mathrm{y}^{\mathrm{e}}$ weste ende of Poules $\mathrm{y}^{\mathrm{e}}$ kynge \& $\mathrm{y}^{\mathrm{e}}$ quene bothe alyghtyd and entryd into $y^{\mathrm{e}}$ churche, \& so into $\mathrm{y}^{\mathrm{e}}$ qwyre, wher they entryd into ij. traversys made for them. And afftar rode forthe. And round abowte $\mathrm{y}^{\mathrm{e}}$ conduyte in Fletestrete was a large \& a fayre greate pageaunte $w^{t}$ turretts \& dyvers other thyngs, Ard at $y^{\mathrm{e}}$ gatte at Temple barr was a longe declaracion of $y^{\mathrm{e}}$ prayse of $\mathrm{y}^{\mathrm{e}}$ kynge, $w^{\mathrm{t}} \mathrm{a}$ bryffe rehearsall of all $\mathrm{y}^{\mathrm{e}}$ sayd pagauntis.

Not., ${ }^{4} y^{t}$ from $y^{\mathrm{e}} 10$ day of Octobar vntyll $\mathrm{y}^{\mathrm{e}} \mathrm{xvj}$. day a greate preparacion was made in Smythefylde for $y^{\mathrm{e}}$ spanyards to bayte $\mathrm{y}^{\mathrm{e}}$ bull aftar $y^{\mathrm{e}}$ maner of Spayne, called Juga de Tauro, vpon sainte Lukes day, \& a great frame for an house newe sett vp ther; and vpon $y^{\mathrm{e}}$ even of saynt Luke, beynge $\mathrm{y}^{\mathrm{e}} \mathrm{xvij}$. day of Octobar, it was knowen $y^{t} y^{e}$ same pastyme shulde be put of, so $y^{t}$ all $y^{e}$ preparacion for this tyme was voyde.

Vpon sent Lukes day, beyng Thursday $y^{e}$ xviij. day of October,

1 Stock Market.

2 Chron. Quecn Mary, p. 8o, gives them as: 'Phillipus rex Macedoniae, Phillipus bonus, Phillipus imperator, and Phillipus audax.'

3 Ironmongers Lane.

4 sc. Notandum. 
$\mathrm{y}^{\mathrm{e}}$ kynges maiestie come to Pawles, and herde masse, $\mathrm{y}^{\mathrm{e}}$ whiche was songe $\mathrm{w}^{\mathrm{t}}$ his awne chapell.

The xxix. of Octobar, $1554, \&$ in $y^{\mathrm{e}}$ first \& second yeres \&c.

John Lyon, grocar, mayre.

${ }^{1}$ Not., that aboute $\mathrm{ij}$. or thre days past those viij. citesins, Wherstone, Emanuell Lucas, Walter Younge, Baskevyle, Wyllyam Bankes, Marten, Kyghlehe, \& Calthrope, wére broughte out of $\mathrm{y}^{\mathrm{e}}$ Flete before $\mathrm{y}^{\mathrm{e}}$ counsell in $\mathrm{y}^{\mathrm{e}}$ Starre chamber, wher as yt was sayd $\mathrm{y}^{\mathrm{e}}$ lordes, consydderynge the obstaclenes, detyrmyned $\mathrm{y}^{\mathrm{t}} \mathrm{y}^{\mathrm{e}}$ sayd [Wherstone] ${ }^{2}$ because he was forman should paye for his fyne a thousande markes, \& euery of $y^{\mathrm{e}}$ other syxe hondreth poundes apece : but yet was not thes fynes ymedyatly sett vppon ther heades, but they were all viij. remytted to $y^{e}$ Flette : $\&$ as for $y^{\mathrm{e}}$ othar fowre, $\mathrm{N}$. Poynter, who neuer came in by reason $\mathrm{y}^{\mathrm{t}}$ he was syke when thother was apprehended, Symon Lowe, merchuaunte tayllor, who had bene delyuered shortly after he was committed, one [ ] Oates, who lately vpon submyssyon was lett out, \& one other, who [s] name I knowe not, were not appoynted to paye any fyne.

And vppon Satterdaye, beinge $\mathrm{y}^{\mathrm{e}} \mathrm{x}^{\text {th }}$ of Nouember, 1554, $\mathrm{y}^{\mathrm{e}}$ shrefe of London enteryd into $\mathrm{y}^{\mathrm{e}}$ houses of $\mathrm{y}^{\mathrm{e}}$ said viij. ${ }^{3} \mathrm{men}, \&$ seased vppon all $\mathrm{y}^{\mathrm{e}}$ goodes in them for $\mathrm{y}^{\mathrm{e}}$ levyinge of a fyne of a thousand markes apece, sett vppon ther heades in thexcheqwyre, \& processe directed vnto $\mathrm{y}^{\mathrm{e}}$ shreffes of London for $\mathrm{y}^{\mathrm{e}}$ levyinge of $\mathrm{y}^{\mathrm{e}}$ same.

Also vppon Mondaye, beinge $y^{e} 12$ day of Nouember, cardynall Poole came vnto Lambeth by water $\&$ ther dyned.

${ }^{4}$ Vpon Sonday, beinge $\mathrm{y}^{\mathrm{e}} \mathrm{xxv}$. day of November, the spanyards made a pastyme before $y^{\mathrm{e}}$ cowrte gate at Westmystar, callid Juga de Cane; for $\mathrm{y}^{\mathrm{e}}$ preparacyon wherof ther was a wall, \& posts pallyd

1 The other hand resumes.

${ }^{2}$ Omitted in MS. at foot of f. $19^{\text {ro }}$.

3 The MS. has ' $x$ iij '.

4 Stow resumes copying. 
dyd enclose $y^{\mathrm{e}}$ tourneyinge place ther, $\& \mathrm{y}^{\mathrm{e}}$ way also was all pullyd vp before $\mathrm{y}^{\mathrm{e}}$ place. $^{1}$

Aboute iij. dayes past $\mathrm{y}^{\mathrm{e}}$ viij. quest men, whose housys were seasyd by $\mathrm{y}^{\mathrm{e}}$ shreves, (as is afore sayd) were asygned to pay $\mathrm{y}^{\mathrm{e}}$ thyrd parte of a M. markes, \& so had ther houssys delyveryd agayn into thandis of theyr wyves, all whiche thyngs was done (as it was sayd) by $y^{e}$ kynges meanes \& procurement : but yet were not they delyveryd ont of pryson.

Vpon Sonday, beynge $y^{-\mathrm{e}}$ second day of Desembar, 1554, and in $\mathrm{y}^{\mathrm{e}}$ fyrste $\&$ second yeres of $\mathrm{y}^{\mathrm{e}}$ reygnes of our soverayne lorde $\&$ ladye Philipp \& Marie, The lorde Chauncelour ${ }^{2}$ made a sermon at Paules crosse, at the whiche sermon $y^{\mathrm{e}}$ kynge $\& \mathrm{y}^{\mathrm{e}}$ cardenall were present, stondynge above ovar the lorde mayres hedd : $\&$ in $y^{e}$ same sermon my lorde Chauncelor declaryd $\mathrm{y}^{\mathrm{t}}$ we had bene long in ignoraunce of derknesse, wherfore accordynge to $\mathrm{y}^{\mathrm{e}}$ wordes of saynt Paule in $y^{\mathrm{e}}$ epystyll redd in $\mathrm{y}^{\mathrm{e}}$ chyrche $\mathrm{y}^{\mathrm{e}}$ sayd Sunday ${ }^{3}$ he exhorted all men $\mathrm{w}^{\mathrm{t}}$ abiiciamus opera tenebrarum, ${ }^{4} \&$ there vpon shewyd $\mathrm{y}^{\mathrm{t}} \mathrm{we}$ must nedes have $\mathrm{y}^{\mathrm{e}}$ pope to be our supreme heade, and $\mathrm{y}^{\mathrm{t}} \mathrm{y}^{\mathrm{e}}$ lorde cardynall Poole was come from hym $w^{t}$ his blessynge vnto vs, who dyd persecute hym $w^{t}$ all maladyccion, and therin (sayd he) owr moaste holy fathar dothe fullfyll $\mathrm{y}^{\mathrm{e}}$ saynge of Christ, whiche is benedicite maledicentibus vobis, ${ }^{5}$ wyllynge $\mathrm{y}^{\mathrm{e}}$ people to put all vayne fantasyes \& ymaginacions ont of theyr heades of any dyscorde to ensewe : for (quod he) a domino factum est istud, ${ }^{6}$ and therfore shall ther be gloria in excelsis deo et in terra pa.x homynybus, ${ }^{7}$ and for because hec est dies quam fecit dominus, exultemus et lctemus in ea, ${ }^{8}$

1 See Machyn p. 76. 'The kynges rydyng at Jube de Cane.'

2 i.e. Gardiner.

3 The first Sunday in Advent: Romans, xiii. 8-14. Wriothesley (ii. 124) gives the text, 'Fratres, scientes quia hora est jain nos de somno surgere' from verse II.

4 Romans, xiii. 12.

5 Matthew, v. 44.

6 Matthew, xxi, 42.

${ }^{7}$ Luke, ii. I4.

5 Psalm, cxviii. 24. 
receyvynge this his holynes benediccionem in one vnytie, ${ }^{1}$ and confessyng our faultes be glad and joyfull to receyve remyssyon. In dede (quod he) this reverend father my lorde cardynall is come to rayse and awake vs all, wher in I exclude not my selffe, for I confesse I have fallyn and am therfore sory $\mathrm{w}^{\mathrm{t}}$ them that be sorye, but as for $\mathrm{y}^{\mathrm{e}}$ kynge \& $y^{\mathrm{e}}$ quene they stode stedfastly allways \& nede not to be raysyd, but he is come to rayse and awake $y^{\mathrm{e}}$ holl body of $\mathrm{y}^{\mathrm{e}}$ realme. And then comynge to his prayers he prayed for $\mathrm{y}^{\mathrm{e}}$ spiritualtye, $\mathrm{y}^{\mathrm{e}}$ temporalltye, \& $\mathrm{y}^{\mathrm{e}}$ sowles departyd, prayenge for $\mathrm{y}^{\mathrm{e}}$ pope as $\mathrm{y}^{\mathrm{e}}$ supreme heade. Aftar this $y^{e}$ belles in Paules began to rynge, $\&$ in othar churchis, whiche made souche noyse that I coulde not vndarstond $\mathrm{ij}$. wordes togethar, \& by reason therof $\&$ allso $\mathrm{y}^{\mathrm{t}} \mathrm{y}^{\mathrm{e}}$ day was furre spent (for it was past one of $\mathbf{y}^{\mathrm{e}}$ clocke) he made a shorte ende.

Vpon Tewesday, $y^{\mathrm{e}} 11$ of Decembar, 1554, Mst. Whetstone, Mst. Yonge, Mst.Bankes, Mst.Baskervyld, and Mst. Martyn were deliveryd ont of $\mathrm{y}^{\mathrm{e}}$ prison of $\mathrm{y}^{\mathrm{e}}$. Flete by vertewe of $\mathrm{y}^{\mathrm{e}}$ quenes leter; \& thothar thre, Emanuell Lucas, Kyghtley, \& Caltrop, were lefte styll behynd in pryson, bycaus they had not payde there parte of $\mathrm{y}^{\mathrm{e}}$ fyne accordynge as thothar fyve had done.

The parlyament endyd aboute $\mathrm{y}^{\mathrm{e}} \mathrm{xxij} .{ }^{2}$ day of Januarie.

Vpon Fryday, beynge $y^{\mathrm{e}} \mathrm{xxv}$. day of Januarie, generall procession ${ }^{3}$ was through Chepesyde downe $\mathrm{y}^{\mathrm{e}}$ one and vp thothar, $\mathrm{y}^{\mathrm{e}}$ byshope of London, $w^{t}$ many othar bysshopes, beynge mytryd, \& $y^{e}$ byshope of London goynge vndar a canapie : and at nyght by $y^{\mathrm{e}}$ comaundement of $y^{\mathrm{e}}$ lord mayre $\& \mathrm{y}^{\mathrm{e}}$ aldarmen bonefyars were made thrwghe out $\mathrm{y}^{\mathrm{e}}$ hole citie $\mathrm{w}^{\mathrm{t}}$ bells ryngynge solomly; all whiche thyngs wer done for Joye of $\mathrm{y}^{\mathrm{e}}$ restorynge of $\mathrm{y}^{\mathrm{e}}$ trewe \& catholyke relygyon, and for $\mathrm{y}^{\mathrm{e}}$ abolysshment of schismes and heresyes.

Vpon Monday, beynge $y^{\mathrm{e}}$ fowrthe of Februarie, one [John] Rodgers, vycar of sent Sepulchres, was burnyd in Smythefelde.

I This is clearly corrupt. 'One' and 'vnytie' have marks of abbreviation over them. Perhaps 'in omni unitate.'

2 Wriothesley (ii. 125 ) says $16^{\text {th }}$ January. Summary, xxii January.

3 The procession of the buck: see Machyn, p. 80.

- Blank in MS. 
Vpon Monday, beynge $y^{\mathrm{e}} 18$ of Februarie, ye byshope of Ely, callyd doctour Hethe, ${ }^{1} \mathrm{w}^{\mathrm{t}} \mathrm{y}^{\mathrm{e}}$ vycounte Broune, ${ }^{2}$ and dyvers othar well apparylyd rode forthe of $\mathrm{y}^{\mathrm{e}}$ citie towards Rome. ${ }^{3}$

Vpon Thursedaye in $y^{\mathrm{e}}$ night, beynge $\mathrm{y}^{\mathrm{e}}$ xiiij. of Marche, $\mathrm{y}^{\mathrm{e}}$ Image of a byshope, ${ }^{4}$ whiche was newly sett $\mathrm{vp}$ of late ovar $\mathrm{y}^{\mathrm{e}}$ dore of sent Thomas of Acars, was shamefully mangled, $y^{\mathrm{e}}$ heade $\& \mathrm{y}^{\mathrm{e}}$ ryght arme beynge cleane smyttyn of : $y^{\mathrm{e}}$ whiche Image ones before this tyme had $\mathrm{y}^{\mathrm{e}}$ hede lykewyse stryken of, and was aftarwarde newly set vp, and nowe eft sones broken.

Vpon Saterday in $y^{e}$ mornynge, beynge $y^{e} x v j$. day of Marche, a wevar whiche dwellyd in Shordyche was burned in Smythefylde for heresye. ${ }^{j}$

Vpon Eastarday, beynge $y^{\mathrm{e}}$ xiiij. day of Aprill, 1555, a certayne desperate person $\mathrm{w}^{\mathrm{t}} \mathrm{a}$ wood knyffe woundyd a priste, as he was mynestrynge the sacrament in sent Margaretes churche at Westmystar, vnto $y^{\mathrm{e}}$ people : of whiche wouncle $y^{\mathrm{e}}$ pryest was in great daunger of deathe, the churche of sent Margaretis was imedyatly shut in, and no more servyce don. ${ }^{6}$

Vpon sent Marks even, beynge Wednysday \& $y^{\mathrm{e}} \mathrm{xxiiij}$. day of Aprell, $y^{\text {e }}$ sayd desperate persone, whiche hurte $\mathrm{y}^{\mathrm{e}}$ priest at Westmystar, was burnyd for heresy at Westmystar in sent Margaretes churche yarde.

Vpon Tewesdaye, beynge $y^{\mathrm{e}}$ vij. day of Maye, a certayn lewd heretyke called Tolly, ${ }^{7}$ a pultar, who aboute $\mathrm{x}$. days past had bene hangyd for robberye, $\&$ had ben buryed betwen Charinge crosse $\&$

1 Nicholas Heath had been already translated to York; it should be Thomas Thirlby.

2 Anthony Browne, viscount Montague.

3 Summary but reading: 'byshop of Ely, with the lord Mountacute.'

4 Thomas Becket. See Wriothesley, ii. 127.

5 Summary, Wriothesley (ii. 127) gives his name Thomas Tompkins.

6 Summary, but adding the miscreant's name (William Flower) and giving more particulars of his punishment.

7 Wriothesley (ii. I 28) calls him John Towley, and says he had been hanged on $26^{\text {th }}$ April, for the robbery of a Spaniard at Shrovetide. 
$\mathrm{y}^{\mathrm{e}}$ gallows ther, was taken $\mathrm{pp}$ agayn and burnyd for certayne sedycious $\&$ hereticall wordes by hym spoken at his deathe. ${ }^{1}$

Itm. in $\mathrm{y}^{\mathrm{e}}$ yere of our lorde $1555, \mathrm{y}^{\mathrm{e}} 26$ daye of August, $\mathrm{y}^{\mathrm{e}}$ kynge $\&$ quene vode thrughe $\mathrm{y}^{\mathrm{e}}$ citie of London, and toke barge at $\mathrm{y}^{\mathrm{e}}$ Towre wharffe, $\&$ so went to Grenewyche.

Itm. $y^{\text {e }} 29$ day of August $y^{\mathrm{e}}$ kynge departyd from Grenewiche $\&$ went in to Spayne.

Itm. in $y^{\mathrm{e}}$ begynnynge of Octobre next folowynge ther was suche raygne $\mathrm{y}^{\mathrm{t}}$ sent Gorgis ${ }^{2}$ felde was coveryd $\mathrm{w}^{\mathrm{t}}$ watar, \& betwen sente Gorgis and Newynton, that for $y^{\mathrm{e}}$ space of vj. dayes whyres myght go ther: and it cam into Westmystar hawle halffe a yarde depe, $\&$ in to $y^{\mathrm{e}}$ palace of Westmynstar, $\&$ in to Lambythe churche, that men mowght rowe aboute $\mathrm{y}^{\mathrm{e}}$ churche $\mathrm{w}^{\mathrm{t}}$ a whyrey. ${ }^{3}$

About $y^{\mathrm{e}} \mathrm{ix} .{ }^{4}$ day of Nouember folowynge $\mathrm{y}^{\mathrm{e}}$ byshope of Wynchest. doctour Styvene Gardenar, departyd this mortall lyffe: and his body was buryed at Wynchestar. ${ }^{5}$

1 The lower half of f. $20^{\text {vo }}$ is left blank.

2 St George's, Southwark.

3 Summary with slight variations. In the Annales, I06I Stow gives a somewhat fuller and different account from Wriothesley's Chronicle, ii. I30.

- On $12^{\text {th }}$ November.

5 The remainder of $f .2 I$ is blank. 


\section{A BRIEF LONDON CHRONICLE}

$$
\text { I } 547-1564
$$

K. Edward the 6. Hobilthor. ${ }^{1}$ mayor

$$
A^{\circ} 2 \text {. }
$$

This yere the kynges ship named the menyon did take a grete spaynysh shyp in the naro sease mannyd weth scott $\&$ halff ladyn $\mathrm{w}^{\text {th }}$ costly goods.

The 15 day of May doctor Smyth ${ }^{2}$ of Oxforde, $y^{t}$ did rede the dyvynite lector at Whitingdon colege, did recant at Poulis crosse.

Doctor Langriche, ${ }^{3}$ archdeacon of Clefland in Yorkeshire, did willfully lepe out of the cloyster of saint Magnus into the Temse, willfully drownyd hymselff yn $y^{\mathrm{e}}$ month of May.

$$
\mathrm{A}^{\circ} 2^{\circ} \mathrm{J} \text {. Gressam, }{ }^{4} \text { mayor. }
$$

In the latter end of Januarii was soche vehement windes that damaged sore the western barges, \& $y^{\mathrm{e}}$ lade barges from London to Grauysende to London : a grocer of this citie, his wyfe, his seruant all were drownyd in a whery, sauyng the seruant $\&$ one of $\mathrm{y}^{\mathrm{e}}$ whery men.

In the latter ende Februarii one of the kynges bregendynes did

1 Henry Hubbarthorne.

${ }^{2}$ Richard Smith (d. ${ }^{563}$ ) see D.N.B. liii. IoI.

3 Richard Langriche, Langridge, or Langreth, Rector of Weldrake, Yorkshire, Archdeacon of Cleveland from 1534, and prebendary of South Muskham, Southwell, from 1538 (Le Neve, Fasti, iii. 148, 432).

- Sir John Gresham. 
take in the naro sease a frenche galeye, browght her into the ryuer of Temse.

In the sermones at saynt Mary Spittell the prechars invayed agaynst the masse. ${ }^{1}$

In June the bysshop of Winchestar was comytted to $y^{\mathrm{e}}$ Towre.

$$
\mathrm{A}^{\circ} \text { 3. Hamcott, }{ }^{2} \text { mayor. }
$$

Ther were dyuerse rebellions yn sondry placis of $y^{\mathrm{e}}$ realme : the mayor \& citizens of Exciter manfully kept $\mathrm{y}^{\mathrm{e}}$ city from the rebelles of Deuonshire, till thei $\mathrm{w}^{\mathrm{t}}$ in were almost famyshed.

This yere was partyes put yn by the nobilite of this realme for the safegard of the kinges royall person, but praysed be God it was gentilly quieted.

500 souldiers of Arde $^{3}$ com nere to Guysnes purposyng to had a great boty of catell; but ther were resisted by the men of Guysnes, \& of $y^{\mathrm{e}}$ men were 50 prisoners takyn, and 103 of them slayne.

\section{Hill, mayor.}

$\mathrm{A}^{\circ} 4^{\circ}$ trynyte terme was reiournyd to myhelmas, ffor that the gentylmen shuld kepe the people quyete $\mathrm{w}^{\mathrm{t}}$ owt comosion. This mayor was a gode mynystrer of Justice, \& a grete ponyssher of adultery.

$$
\left[\mathrm{Jud}^{4}\right] \text { mayor. }
$$

In $\mathrm{a}^{0} 5$ be reson that $\mathrm{o}^{\mathrm{r}}$ mony was so base the exchaunge to Andwarp was vnder $17 \mathrm{~s}$. the li.

In May there cam a hoye to London $w^{t}$ Holond chese, whiche was solde for $2 d$ the $1 \mathrm{~b}$., and that after the rate of Essex chese vj. s. the way.

${ }^{1}$ Of Wriothesley Chron. ii. 2.

2 Sir Henry Amcotes.

3 Ardres.

1 'dobs' was written in MS., but afterwards crossed out. 


\section{Dobs, mayor.}

$\mathrm{A}^{\circ}$ 6. the erle of Arundell \& the lorde Paget were comytted prisoners to the Tower. The erle was afterward relesed, the lorde Paget by a chapter of $y^{e}$ knyghtes of the gartar clymyssed from the same order.

\section{Barns, mayor. Quene Mary.}

When the bisshop of Win., chaunceler, did mynyster the othe to Justices of this realme he wolde not mynyster to Justice Halis, ${ }^{1}$ ffor he sayde he had to talke $\mathrm{w}^{\mathrm{t}}$ him in maters of religion.

The ix. of September $\mathrm{y}^{\mathrm{e}}$ archebyshop of Cauntorbery and $\mathbf{M}^{\mathrm{r}}$ Latymer wer comytted prisoners to the Tower.

\section{T. Whight, mayor.}

$\mathrm{A}^{\circ} 1^{\circ}$. the 13 of Nouember the lady Jane, before proclaymyd qwene, $\&$ the archebysshop of Cauntorbery wer araigned at the gwylde hall ffor treson, \& shortly after she was beheded at the Tower hill.

In Feuerer the archebysshop of Cauntorbery, doctor Ridleye, \& $\mathrm{M}^{\mathrm{r}}$ Latymer were remouyd from the Tower to Oxford.

\section{Ironmonger. ${ }^{2}$}

In Marche died Julius, ${ }^{3}$ bisshop of Rome, for whom ye qwene caused a solem funerall seruice to be done at Powlis.

In the iij. yere the qwen did remyt the first frute of $\mathrm{X}^{\text {ths }}$.

$$
\text { Garett, }{ }^{4} \text { mayor. }
$$

Doctor Gardynar, bisshop of Winchester \& chaunceler died.

1 Sir James Hales. See D.N.B. xxiv. 29. See also Grafton, Chronicle, ii. 537.

3 This is inserted; ' ironmonger ' had first been written after the next sentence. The mayor for I 554-55 was John Lion, grocer.

3 Julius IIl died on $5^{\text {th }}$ March, 1555 ; the service for him at St Paul's was on I $7^{\text {th }}$ April, see Wriothesley, Chron. ii. 127.

4 Sir William Gerard. 


\section{Ofley, mayor.}

In January the bodies of $\mathrm{M}^{\mathrm{r}}$ Bucor, $\& \mathrm{M}^{\mathrm{r}}$ Fabius ${ }^{1}$ wer takyn out of theire grauys, \& burnt in the market place of Cambrige :

v. Shipes of Brystow ladyn $\mathrm{w}^{\mathrm{t}}$ marchandise owt of Spayne were takyn by 7 ships of war of Fraunce.

In the tyme of the raigne of this qwene there were burnyd, and som allso that died in prison for religion. lityll vnder or ouer 2040 men \& women.

In the begynnyng of Julii iij. shipes of this citye comyng from Andwarp ladin $w^{t}$ riche marchandise were takyn by Scottes and Frenchemen, whiche were estemyd to be better worth than 20000 li.

\section{Quene Elisabeth. Leigh, mayor,}

In $\mathrm{a}^{0} 1^{\circ}$ no thing to noate.

\section{Hewet, mayor.}

$\mathrm{A}^{\circ} 2^{\circ}$ the qwene did send $\mathrm{ij}$. of her ships to the see to take a pirate namyd Strangwysh, ${ }^{2}$ who $\mathrm{w}^{\mathrm{t}}$ his $\mathrm{ij}$. ships \& $\mathrm{ij}$. other capitaynes $\mathrm{w}^{\mathrm{t}}$ owt makyng of any resistence did yelde.

\section{Chestar.}

There was so grete scarsety of corne that $\mathrm{y}^{\mathrm{e}}$ mayor $\&$ citizens made prouyson for wheat \& rye $30000 \mathrm{q}^{\text {rs }}$ from beyond the se.

\section{Harpour, mayor.}

The occasion whervppon the qwene did send to New hauyn was the lorde Vidame, capitayne of New hauyn, \& the bayly of Roen, ${ }^{3}$ the treasorer of Deep ${ }^{4}$ offered the forsayde townys to the qwenes

1 Martin Bucer, and Paul Fagius; the date of their exhumation was $6^{\text {th }}$ Feb., I557.

2 Machyn, Diary, 206, 212-3. Strangwysh was brought to the Tower on IO $^{\text {th }}$ August 1559.

${ }^{3}$ Rouen.

+ Dieppe. 
magesty, if it wolde please her to further them in theire procedinges of the gospell, for that her mageste is right inheritor to $y^{\mathrm{em}} \&$ to all Fraunce. ${ }^{1}$

\section{Lodge, mayor.}

$\mathrm{A}^{\circ} 5^{\circ}$ in Marche all the English marchantes $\mathrm{w}^{\mathrm{t}}$ ther goodes \& shipes wer arested al Burdeus.

The men of Plymmoth did take 14 brettysshe ships $w^{\text {t }}$ salt $\&$ wyne.

The men of Seaton \& legis from the towne of Deepe did take 15 crayers to New hauyn $w^{t}$ vitayll at sondry tymes.

A man of Plymmoth namyd Hawkins, ${ }^{2}$ did take a French ship comyng from Gynys wholely ladyn.

A crayer of Rye $w^{t} 30$ men in her did take a ship in Deep rode, $\&$ if there had bene more men they might haue takyn one other ship.

A passenger of Douer sayling to Dunkirk was takyn by a hayne of Diepe comyng owt of Cales, \& conuayed to Calies, \& there put them to their ransom.

The forsayde hayne was well knowen to $y^{\mathrm{e}}$ men of Douer, that he was a comen saylor betwene Diepe and Caleis: Thes men of Douer $\mathrm{w}^{\mathrm{t}} \mathrm{a}$ crayer well mannyd lay in wayte for hym shortly after betwen Bolen and Cales, \& did take him ladyn $w^{t}$ canuas $\&$ howsolde stuff to Dales, whiche was to them a gode recompence.

In this somer did fall so greate aboundance of rayne in Zeland that hops were so scant that they were solde in London for liij. $s$. iiij. $d$. the C. ; \& some bere breuars practised to brew $\mathrm{w}^{\mathrm{t}}$ brome $\&$ some $w^{\text {t }}$ bay beries.

\section{John Whight, mayor.}

In the begynnyng of Nouember 24 western ships did toke 17 bretisshe ships laden $w^{t}$ wyne, and if one of the

had not bene

1 This seems to be quoted by Stow, Annales, I10I. ed. 1605.

2 Presumably John Hawkyns, who came home from his first voyage to the Spanish Main in Sept., 1563 . 
to hasty, ther myght have takyn many mo: the brytons had 4 men of warre for theire waffters, but whan thei did see so grete a flete of englyshe men of war they fled.

$A^{\circ} 6$, in the begynnyng of December was so greate lyghtenyng $\&$ horrible thonder that the lyke was not seen $\mathrm{w}^{\mathrm{t}}$ the remembraunce of any man lyuyng. ${ }^{1}$

Remember the monstrous fysshe."

In the month of July sesed the plage, that did begin the last yere.

In the 30 day of August it was enacted that all soche as wolde sell their waris, plate or howsold stuff to theire most aduantage, for the paying of $\mathrm{o}^{\mathrm{r}}$ dettes or elles for the fordell of orphans, sholde bring the same waris \&c. to Ledyn hall on Monday \& Friday, there to be solde to them that wolde gyue most for it. ${ }^{3}$

In this yere was browght to $\mathrm{y}^{\mathrm{e}}$ citie great plente of frute, for ther cam in one market in to Southwark " cartes $\mathrm{w}^{\mathrm{t}}$ frute, in to Graschirche strete xiiij. cartes, besids a greate qwantytie that was browght on horsbacke, in panyers and dossars : this contynuyd the moste parte of the somer.

1 Summary p. 275; Annales p. 1103.

2 No doubt a whale; it was driven ashore at Grimsby, was 19 yards long and yielded two tons of oil. See Summary, which is much fuller than Annales.

3 Summary with considerably more detail. Omitted in Annales.

4 The MS. is damaged. 
. 


\section{N D E X}

\section{A}

Albury, 23.

Aldermary, see St Mary.

Aldersgate St., 36 .

Aldgate, 28.

Allen, John, a priest, I4.

Allen, or Allyn, Sir John, I I.

Allhallows Barking, ro.

Allhallows, Bread St., 6, 7 .

Allyn see Allen.

Amcotes, Sir Henry, I 7, 45.

Andrew Moreys Quay, 3 .

Antwerp, (Andwarp), 45, 47.

Arden of Faversham, 22.

Ardres, 45 .

Arthur, prince of Wales, 7 .

Arundell, Earl of, see Fitzalan.

Arundell, Humphrey, I 7, 20.

Arundell. Sir Thomas, 26.

Askew, Christopher, 8.

Audley, Sir Thomas, 6.

Austin friars, 9.

Axholme, (Exsam), xo.

\section{B}

Baldry, Thomas, 2.

Bangor, bishop of, see Salcot, John.

Barnes, George, 26, 46.

Barns, Robert, 2.

Barton, Elizabeth (Anne) the Holy

Maid of Kent, 8, 9.

Baynam, 6.
Baynards Castle, 8, 27.

Bell, a Suffolk man, 21 .

Bermondsey Priory, I2.

Beauvale, 10.

Berrys, or Bery, a rebel, 20.

Bilney, or Bylneye, Thomas, 5.

Bishop Clist, 17, 18.

Black friars, 14.

Blackwall, 9 .

Bletchingley, 23.

Bocher, Joan, 21.

Bockyng, Edward, 8.

Boleyn, Ann, Queen, 7, 8, 9.

Boleyn, Sir Thomas, Earl of Wiltshire, 4,7 .

Bonner, Edmund, bishop of London, 29, 3I, 4r.

Bordeaux, (Burdeus), 48.

Boulogne, (Bulloyne, Bolen), 7, 21, 48.

Bowes, Sir Martin, I7.

Bowler, a rebel, 18.

Boyer, William, 16.

Bread St., 6, 7, 9.

Bret, Alexander, 33, 34.

Bretons, 48, 49.

Bridewell, 2.

Bristol, 47.

Broad Causeway, Westminster, 25.

Broken Wharf, 9.

Browne, Anthony, Viscount Montague, 42.

Bryce, Hugh, I.

Bucer, Martin, 47.

Bylneye, Thomas, 5 . 
C

Calais, 7, 26, 48 .

Cambridge, 2, 3, 27, 28, 47 .

Canterbury, 8, 9, 22.

Canterbury, Archbishops of, see Cranmer, Pole.

Carew, Sir Nicholas, 15.

Carow, Charles, 16.

Catherine of Aragon, Queen, 7, 8, 27.

Champneys, John, ro.

Chantries, 13.

Charing Cross, 9, 42.

Charterhouse, The 10, 15, I6.

Cheap, Cheapside (Chepe), I, 2, 4, $8,14,19,25,27,34,41$.

Cheap Cross, I, 5, 34, 36 .

Cheeke, Sir John, 28.

Chessher, Thomas, 16.

Chester, William, 47.

Chipping Norton, 18.

Cholmley, Sir Roger, 28.

Christchurch, or Trinity Priory, 6.

Clarke, Griffith, I 5 .

Cleveland, 44.

Cobham, Lord, 3 I.

Cobham, Thomas, 33 .

Coinage, coiners, 2, 4, 6, 14, 23 , 24.

Cooke, Laurence, I6.

Corbyt, Sir Richard, 28.

Cornwall, I7.

Cotes, John, I6.

Counters, 'The, 34 .

Courtenay, Edward, Earl of Devonshire, 29, 34 .

Court-up-street, 8.

Cranmer, Thomas, Archbishop of Canterbury, 19, 22, 31, 35, 46.

Crofte, Elizabeth, 36 .

Cromwell, Thomas, Earl of Essex, $9,15,16$.

Croydon, 23.
D

Dacre of the North, Lord, 9.

Darcie, Thomas, Lord, 14.

Daunce, Hary, see Harridaunce.

Deryng, Richard, 8.

Devonshire, Earl of, see Courtenay

Devonshire, I 7, 45 .

Dieppe, $47,48$.

Dobbes, Richard, 24, 46.

Dodmer, Ralph, 4.

Dolman, Dr., 3 I.

Doncaster, 16 .

Dormer, Michael, I6.

Dover, 48.

Dudley, Ambrose, 28.

Dudley, Sir Andrew, 28.

Dudley, Guilford, 31, 33 .

Dudley, Henry, 28, $3 \mathrm{r}$.

Dudley, John, Earl of Warwick, and Duke of Northumberland, 19, 21, 24, 27, 28, 29.

Dudley, Robert, $3 \mathrm{I}$.

Dunkirk, 48.

Dutchmen, 2, 5, 23, 30.

\section{E}

Edward VI, King, $17-26,29,44-46$. Elizabeth, Queen, 27, 35, 36, 4749.

Elsing Spittle, 12.

Esher, 4 .

Essex, Earls of, see Cromwell, Parr.

Essex, 21 .

Ewell, Thomas, 14.

Exeter, I 7, 45.

Exmew, William, ro.

Exsam, see Axholme.

\section{F}

Fagius, Paul, 47.

Fenchurch, 29. 
Finsbury Field, 2, 4, 5, 6 .

Fires, 3, 4, 7, 8, 9, 14.

Fisher, John, bishop of Rochester, 5 , 10.

Fitzalan, Henry, Earl of Arundel, $27,46$.

Flanders, 25.

Fleet St., 33, 38.

Fleet Prison, 35, 39, 4r.

Flower, William, 42.

Forman, William, 14 .

Fostar, a heretic, 3 .

Framlingham, 27.

France, 2, 48 .

Francis I, King of France, 3.

Frith or Frythe, John, 7, 9.

\section{G}

Gambold, or Gambo, Peter, 20.

Gardiner, Stephen, bishop of Winchester and Chancellor, 22, 29, 3 I, 40, 4I, 43, 45, 46 .

Gates, Henry, 28.

Gates, Sir John, 28, 29.

Gavaro, Charles, 20.

Gerard, Sir William, 46.

Godstone, 23.

Gold, or Goulde, Henry, parson of Aldermary, 8, 9.

Gold, Thomas, 8.

Gracechurch, 4, 29.

Gracechurch (Gracious) St., 3o, 38,49 ,

Gravesend, I, 28, 30, 44 .

Gray's Inn, 7 .

Great Conduit, The, 34 .

Greenwich, 2, 6, 9, 32, 43 .

Gresham, Sir John, I 7, 44.

Gresham, Richard, I4.

Grey, Henry, Duke of Suffolk, 24, $28,33,35$.

Grey Lady Jane, 3I, 33, 46.

Grey of Wilton, William, Lord, I $7,18,24,26,28$.
Grey friars, 9, 15.

Gryffyn, Rhys, 5 .

Guildhall, The, 3I, 35, 46,

Guisnes, 26, 45, 48 .

\section{$\mathrm{H}$}

Hales, Sir James, 46.

Hall, Edward, 7, ro.

Hampton Court, x 9, 20.

Harford, Thomas, 14.

Harper, William, 47.

Harman, a coiner, 2.

Harmond, a searcher of Gravesend, 28.

Harpsfield, Nicholas, 37 .

Harridaunce, John, 15 .

Harssam, Harry, I4.

Hastings, Francis, Earl of Huntingdon, 28.

Hastings, George, Earl of Huntingdon, 4 .

Havre, or New Haven, 47, 48.

Hawkyns, Sir John, 48.

Hayle, John, Io.

Heath, Nicholas, Archbishop of York, 42.

Henry IV, I.

Henry VII, I.

Henry VIII, I-I 7 .

Herbert, Sir William, Earl of Pembroke, 17, 24, 27.

Heresy, and heretics, I, 3, 5, 7, 8, IO, I3, I5, 2I, 23, 4I, 42 .

Herne, or Horne, Giles, 16.

Hewet, William, 47.

Hewitt, Andrew, 7, 9.

Hill, Sir Rowland, I9, 45.

Holborn, 7, 16.

Holland, 10.

Holles, William, 15.

Holmes, Thomas, 21 .

Honey Lane, 3.

Honiton, $\mathrm{x} 7$.

Horne, parson of St. Nicholas Willows, 24. 
Howard, Thomas, Duke of Norfolk, 29, 34 .

Howard, Lord William, 26.

Hubberthorne, Sir Henry, I7, 44.

Humber, 25.

Hungerford, Agnes, Lady, 2.

Hungerford, Walter, Lord, i 6.

Huntingdon, Earls of, see Hastings.

Hussey, John, Lord, I4.

\section{I}

Isleworth (Thystylworth), ro.

Isley, or Illisleye, Sir Henry, 3I, 33.

\section{J}

Judd, Andrew, $21,45$.

Julius III, Pope, 46.

\section{K}

Kendall, Thomas, 13.

Kent, 8, 21, 31, 34 .

Kett, Robert, 18, 19.

King's Head, The, Smithfield, 20.

Kingston, 32.

Knevett, Master, 4.

Knevet, William, 33.

\section{L}

Lacie, Mr., 5, 6.

Lambard, Nicholas, 5 .

Lambert, John, 15 .

Lambeth, 22, 39, 43.

Lambeth marsh, 9 .

Langriche, Richard, 44.

Latimer, Hugh, $35,46$.

Laxton, Sir William, I6.

Leadenhall, 4, 32, 49.

Lee, Thomas, Ir.
Leicester, 33 .

Leigh, Thomas, 47.

Lesnes, 25.

Lincoln, 13 .

Lodge, Thomas, 48.

Lombards, 9.

London, bishops of, see Bonner, Ridley.

London Bridge, 9, 33, 38 .

Louth, 13.

Lowe, Simon, 35, 39, 40, 4r.

Lucas, Emanuel, 35, 39, 40, $4 \mathrm{r}$.

Ludgate, 33.

Luther, Martin, 3.

Lyon, John, 39.

\section{M}

Makkarell, Matthew, 13.

Marching-watch, the, 5, 15 .

Marshalsea, The, 15, 29.

Mary, Queen, 7, 27-43, 46-47.

Mary of Guise, Queen of Scotland, 25.

Masters, Richard, 8.

Mercers Hall, 19.

Mews, The, at Charing Cross, 9.

Middlemore, Humphrey, 10.

Middleton Stony, 26.

Mile End, 2.

Miles, Dr. Nicholas, 4.

Montague, Sir Edward, 28.

Montague, Viscount, see Browne.

More, Sir Thomas, 4, 6, Io, 1 I.

Morysbye, Thomas, 22.

Myryll, a tyler, 13 .

\section{$\mathrm{N}$}

New Abbey, London, 12.

Newark, 9.

Newcastle, 9.

Newdigate, or Nydygate, Sebastian, 10. 
Newgate, 2, 4, 6, 13, 14, 20, 26, 34 .

New Haven, or Havre, $47,48$.

Newington, 43.

Newman Thomas, 13.

Norfolk, 18.

Norfolk, Duke of, see Howard.

Northampton, Marquis of, see Parr.

Northamptonshire, 18.

Northumberland, Duke of, see Dudley.

Norwich, 18, 9.

\section{$\mathrm{O}$}

Observant friars, 9 .

Ofley, Thomas, 47 .

Oxford, 7, 35, 44, 46 .

Oxfordshire, 18, 26.

\section{$\mathbf{P}$}

Packenton, or Packington, Robert, 13.

Paget, William, Lord, 19, 27, 46 .

Palmer, Sir Thomas, 24, 28, 29.

Pagetor, Sir Thomas, 4, 14.

Parnyll, 5.

Parr, William, Marquis of Northampton, $18,28$.

Partridge, Sir Miles, 24, 26.

Patchett, Sir Thomas, 19.

Pattmer, a priest, 5 .

Paulet, William, Marquis of Winchester, 24.

Pavyar, town clerk, 7.

Paytmer, a glazier, 5 .

Pecocke, Stephen, 7.

Pembroke, Earl of, see Herbert.

Philip of Spain, 31, 32, 36, 37, 38, 43.

Philpot, or Fylpot, Clement, 16.

Pillory, The, in Cheap, I4.

Plymouth, $14,48$.
Pole, Reginald, Cardinal, 39.

Pomeroy, Sir Thomas, I 8.

Pursar, John, 5.

\section{$\mathbf{R}$}

Radcliffe, Robert, Earl of Sussex, 4 .

Raynolds, a Carthusian, ro.

Rich, Hugh, 8.

Richard II., I.

Richmond, 8, 9, 36.

Richmond, Henry, Duke of, 2.

Ridley Nicholas, Bishop of London, $26,27,28,35,46$.

Risby, Richard, 8.

Rhodes, (Rodes) Master of the, 3 .

Roche, William, 16.

Rochester, 33.

Rochester, bishop of, see Fisher.

Rode Lane, 14.

Rogers, John, 4I.

Rome, 3, 42.

Rouen, 47.

Rudstone, John, 3.

Russell, John, Lord, 7 .

Rycote, Oxfordshire, 18,36 .

Rye, 48.

\section{S}

St Andrew by the Wardrobe, 6 .

St Antholin's, 4, I4.

St Anthony's School, 3, Ir.

St Bartholomew's Priory, 12.

St Bride, Fleet Street, 4.

St George's Field, Southwark, 43.

St James' Palace, 25, 33.

St John, the Lord of, $\mathbf{9} 9$.

St John's Priory, 3.

St Katherine's, 25.

St Magnus, 44.

St Margaret's, Friday St., 15.

St Margaret's, Westminster, 42.

St Mary Aldermary, 8. 
St Mary Overy, 7, 12.

St Mary Spittle, 12, 45.

St Nicholas Willows, 22, 24.

St Paul's, 1, 2, 3, 5, 6, 12, 15, 22, $25,29,30,31,38,39,46$.

St Paul's Cross, 6, 8, $13,15,27,34$, $36,37,40,44$.

St Paul's School, I1.

St Sepulchre's, 13, 41.

St Thomas of Acre, II, I3, 42.

St Thomas Watering, 15 .

Salcot, John, bishop of Bangor, 8.

Salters Hall, 9.

Sandys, Edwin, 28.

Seamar, Thomas, 2.

Seaton, 48.

Seymour, Anne, Duchess of Somerset, 24, 29.

Seymour, Edward, Duke of Somerset, I 9, 20, 21, 24, 25, 26.

Seymour, Thomas, Lord, 17.

Shoreditch, 42.

Skotte, John, 4.

Smith, Dr. Richard, 44.

Smith, Sir Thomas, 19, 20.

Smithfield, 3, 5, 6, 7, 10, 15, 20, $21,22,23,38,41,42$.

Somar, Thomas, 5 .

Somerset, I 8.

Somerset, Duke of, see Seymour.

Sothewell, Sir Robert, 34 .

Southwark, 7, 20, 32, 34, 38, 43, 49.

Spain, I, 43, 47 .

Spencer, James, 3 .

Standard, The, in Cheap, 4. 8.

Stanhope, Sir Michael, 20, 24, 26.

Stansted, I3.

Star Chamber, 39.

Steelyard, The (Stilaard), 2, 29, 38.

Stocks, The, 38 .

Strangwysh, or Strangways, pirate, 47.

Stratford, 2.

Suffolk, I8, 2 I.
Suffolk, Duke of, see Grey.

Suffolk Place, Southwark, 20, 38.

Sussex, Earl of, see Radcliffe.

\section{T}

Taylor, John, Master of the Rolls, 9.

Temple Bar, 9, 33, 38 .

Thame, 18 .

Thames, 2, 22, 25, 45 .

Thirlby, Thomas, bishop of Ely, 42 .

Thomas, William, 35.

Thomson, Harry, 5 .

Throckmorton, Nicholas, 35, 39, 40, 4 I.

Thwaytes, Edward, 8.

Tompkins, Thomas, 42.

Tower of London, The, 5, 6, 8, 9, I I, I4, 15, I6, I 9, 21, 22, 24, 27 , $28,29,33,34,35,36,45,46$.

Tower Hill, $4,5,6,10,15,16,17$. $25,26,3 j, 35$.

Tower Wharf, 43 .

Towley, or Tolly, John, 42.

Trinity, or Christchurch Priory. London, 6.

Tunstal, Cuthbert, bishop of Durham, 29.

Tyburn, 2. 5, 9, 10, 13, 14, 16, 2 I, 36.

Tyndal, William, 5 .

\section{V}

Vane, Sir Ralph, 24, 26.

Vintry, The, 4.

\section{W}

Wandsworth, $\mathrm{I}_{5}$.

Warwick, Earl of, see Dudley.

Warryn, or Warren, Ralph, 13. 
Watling Street, 24.

Wayre, a friar, 15 .

Westminster, 4, 8, 9, 10, 12, 13, 14, 16, 20, 30, 33, 35, 39, 42, 43 .

Westminster Abbey, 29, 34 .

Westminster Hall, 25, 43.

Whetstone, or Wherstone, Thomas, $35,39,40,4 \mathrm{I}$.

White, Sir John, 48.

White, Sir Thomas, 30, 46.

White friars or Carmelites, 15.

Whittington College, 44 .

Wiclif, John, I.

Williams, Sir John, I8, 36 .

Wiltshire, Earl of, see Boleyn.

Winchester, 37, 43 .

Winchester, bishop of, see Gardiner; Marquis of, see Paulet.

Windsor, $7,19,20,36$.

Wolffe, a murderer, 8, 9.
Wolsey, Thomas, Cardinal, 2, 3, 4 .

Woodstock, I 8, 36 .

Woolwich, 25.

Wrestling-place, The, I4.

Wyatt, Sir Thomas, 3I-35.

Wynslowe, 一, 2 I.

\section{$\mathrm{Y}$}

York, Archbishops of, see Heath, Wolsey.

York Place, (Whitehall), 4.

Yorke, John, 2I.

\section{Z}

Zeeland, 48. 


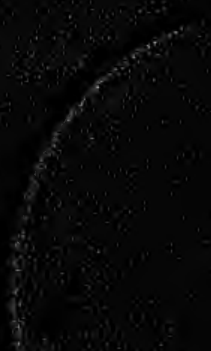

3.2. 